IZA DP No. 6968

The Determinants of Rural Migrants' Employment

Choice in China: Results from a Joint Estimation

Yuling Cui

Daehoon Nahm

Massimiliano Tani

October 2012 


\title{
The Determinants of Rural Migrants' Employment Choice in China: Results from a Joint Estimation
}

\author{
Yuling Cui \\ Macquarie University \\ Daehoon Nahm \\ Macquarie University \\ Massimiliano Tani \\ Macquarie University \\ and IZA
}

\section{Discussion Paper No. 6968 \\ October 2012}

IZA
P.O. Box 7240
53072 Bonn
Germany

\author{
Phone: +49-228-3894-0 \\ Fax: +49-228-3894-180 \\ E-mail: iza@iza.org
}

\begin{abstract}
Any opinions expressed here are those of the author(s) and not those of IZA. Research published in this series may include views on policy, but the institute itself takes no institutional policy positions. The IZA research network is committed to the IZA Guiding Principles of Research Integrity.

The Institute for the Study of Labor (IZA) in Bonn is a local and virtual international research center and a place of communication between science, politics and business. IZA is an independent nonprofit organization supported by Deutsche Post Foundation. The center is associated with the University of Bonn and offers a stimulating research environment through its international network, workshops and conferences, data service, project support, research visits and doctoral program. IZA engages in (i) original and internationally competitive research in all fields of labor economics, (ii) development of policy concepts, and (iii) dissemination of research results and concepts to the interested public.
\end{abstract}

IZA Discussion Papers often represent preliminary work and are circulated to encourage discussion. Citation of such a paper should account for its provisional character. A revised version may be available directly from the author. 


\section{ABSTRACT \\ The Determinants of Rural Migrants' Employment Choice in China: Results from a Joint Estimation}

This paper investigates the determinants of employment choice of rural migrant workers across state-owned enterprises (SOEs) and various subtypes of non-state owned enterprises (non-SOEs) by taking into account unobservable characteristics that link the choice to migrate with the choice of employer. Using pooled cross-section data for 1995 and 2002, the results indicate that the choice of employment is positively related to unobserved determinants of migration. This result implies that estimating employment choices without controlling for migration status leads to biased estimates. Most rural migrants appear strongly pulled into non-SOEs because of the higher wages and despite longer working hours. The provision of pension benefits also positively motivates employees' choices.

JEL Classification: $\quad \mathrm{C} 35, \mathrm{~J} 21, \mathrm{~J} 61$

Keywords: $\quad$ rural migrant workers, employment choice, SOEs, non-SOEs, China

Corresponding author:

Massimiliano Tani

Department of Economics

Macquarie University

NSW 2109

Australia

E-mail: max.tani@mq.edu.au 


\section{Introduction}

Since 1978 China has undertaken substantial reforms towards the creation of a market-oriented labour demand, with new forms of privately-owned enterprises, and supply, with eased restriction to the internal movement of people. As new firms sprang up in cities, especially in those along the coastal regions, and progress in the agricultural sector led to increasing surplus of labour in interior regions, rural-urban migration took off. In 2011, the number of Chinese rural migrants bypassed 153 million people, $75 \%$ of whom were employed in non-state owned enterprises (nonSOEs). A large literature has followed these developments, highlighting the determinants of migration (e.g. Zhao, 1999b; 2003; Zhu, 2002) and the choice of employment; (e.g. Roberts, 2001; Wang, 2005; Gagnon et al., 2009; Démurger et al., 2009).

One feature of existing studies however is that the choice to migrate is analysed separately from the choice of employment. Yet, this approach is open to criticism, as these two choices may be related. It is unlikely that migrants go to a city without knowledge of where to stay, whom to contact to get a job, and how to get information, or shelter. As a result, rural migrants may not face an unrestricted choice of employment that can optimise their utility. Rather, they may face only a limited set of alternatives that depend, at least in part, on some characteristics that affect their choice to migrate. These may not by captured by the estimates of the determinants of migration, especially when they are not observed. For example, it is well known that the allocation of jobs in state-owned enterprises (SOEs) is still controlled by the government (e.g. Brooks \& Tao, 2003), and that rural migrants not only have limited rights of access to the urban welfare system but they cannot apply to urban-based jobs 
because of their rural-hukou ${ }^{1}$ (Cai, 2001). Those institutional impediments and/or labour market barriers are hardly included in the statistical analyses of migration and employment choice, but are a possible source of bias. Correctly identifying the key drivers of employment choice across different types of enterprises is relevant to better understand the development and functioning of the urban labour market in China's transitional economy.

This paper contributes to fill this gap by testing whether unobserved factors related to the decision to migrate also affect the employment choice of rural-urban migrants. In particular, we apply a nested logit model to cater for the decision to migrate and to work for SOEs or various subtypes of non-SOEs using data from the Chinese Household Income Project (CHIP) for 1995 and 2002. The results suggest that indeed unobserved variables affecting the decision to migrate also significantly affect the choice of employer, and hence ought to be catered for in labour market analyses of rural-urban migration.

The rest of the paper is organised as follows: section 2 briefly reviews the existing literature. Section 3 presents the methodology. Section 4 summarises the data while the empirical results are reported in Section 5. Section 6 concludes. The Appendix provides a historical background of the main reforms introduced in China on both demand and supply of labour.

\section{Literature review}

For decades, since the late 1950s, the mobility of Chinese population between rural and urban areas has been controlled by the strict household registration (hukou)

\footnotetext{
${ }^{1}$ The household registration (hukou) system generally divides individuals into those who have ruralhukou if they live off agricultural production and their household registrations are in rural areas, and those who have urban-hukou if their food supplies are rationed by the state. Migrants from rural areas possess a rural-hukou.
} 
system. This system registers each person at a specific location and defines each individual as a household type (Goodkind \& West, 2002). Rural-urban migration has historically excluded rural migrants from the urban welfare system, which covers job allocation, housing, education, pension, medical care and other services (Cai, 2001). With the introduction of the Household Responsibility System (HRS) ${ }^{2}$ and the consequent increases in productivity and labour surplus in the rural sector, a series of reforms on the hukou system began to be implemented since 1978. These were intended to reduce unemployment pressures in China's rural provinces by relaxing administrative regulations on rural-urban migration (see Table A1 in the Appendix). These measures included providing rural migrants with food and housing, free employment information, policy consultation, vocational training relevant to market needs, and abolishing limitations on the number of rural migrants who can apply for permanent residence in medium-sized cities $^{3}$ and some provincial capitals. As a result, a large number of rural migrants began to seek employment opportunities in urban areas.

Research on the driving forces of rural-urban migration has mostly pointed to the income gap between rural and urban areas as a key determinant of migration, as per the Todaro (1969) and Harris and Todaro (1970) models. In that framework an individual decides to migrate if the expected wage of working in a city (i.e. the wage adjusted for the probability of finding employment) is still above the actual wage received at home, in agriculture. According to the National Bureau of Statistics of China (NBSC), per capita income in urban areas was 3.1 times that in rural areas for

\footnotetext{
${ }^{2}$ The HRS denotes that rural labour can contract land and other resources with local authorities. As a result, they can obtain output quotas. This system breaks the collectivization of agriculture, returns some degree of personal freedom to rural individuals, and improves the agricultural productivity (Lin, 1988; Zhao, 1999a).

${ }^{3}$ Medium-sized cities denote those whose population is between 200 thousand and 500 thousand.
} 
the $1978-2000$ cohort, which reduces to 2.5 times once inflation is taken into account (e.g. Johnson, 2002). Using data from a 1993 survey carried out in Hubei, Zhu (2002) supports that the income gap between rural and urban areas is a positive determinant of internal migration.

Aside from a pecuniary incentive, the literature has highlighted that rural individuals migrate when there is a pre-existing network of family and friends in the would-be urban destination (e.g. Rozelle et al., 1997; Zhang \& Li, 2003; Zhao, 2003) and when uncertainty about land rights prevails in the rural home village (Zhao, 1997; 1999a; Zhu, 2002).

Among personal characteristics, the probability of migration decreases with age (Zhao, 1997; 1999a) while it does not appear particularly affected by the amount of formal education (e.g. Hare, 1999), with a possible exception for male migrants (Zhu, 2002).

A somewhat separate line of research has focused on migrants' employment choices. In China’s urban labour market the emergence of non-SOEs since 1978 has broadened employment opportunities to a mixture of government-owned and marketoriented enterprises, which apply different wage policies. Non-SOEs include urban collective-owned enterprises (UCEs), private enterprises, self-employed enterprises, foreign-invested enterprises (FIEs), and joint-venture enterprises (JVs). These firms have been progressively able to enter operations besides retail and wholesale industries into consulting services, investments, imports and exports with consequent expansion in both their share of the gross industrial output value (see Fig. A1), and urban employment (Table A3). 
A number of studies highlight the development of non-SOEs and their main differences with SOEs (e.g. Zhang, 2004; Brooks \& Tao, 2003; Chow \& Ngo, 2002; Fan, 2001), and the reforms put in place to enable SOEs to withstand the increased competition from the private sector ${ }^{4}$. This literature also shows that despite different wage and employment benefit structures, rural migrants are more likely to choose non-SOEs (e.g. Knight et al., 1999; Lu \& Song, 2006), while urban residents prefer SOEs (e.g. Zhao, 2002; Knight \& Li, 2005).

Statistical analyses on the determinants of employment choice support that wage differences between SOEs and subtypes of non-SOEs matters (e.g. Dong \& Bowles, 2002), as does the presence of employment benefits (e.g. Miyamoto \& Liu, 2004), consistently with what observed for other countries transiting from a centralised to a market-based economy (Bedi, 1998; Adamchik \& Bedi, 2000). Preference for non-SOEs is also positively affected by being young and male, and married (e.g. Roberts, 2001; Christofides \& Pashardes, 2002; Wang, 2005; Gagnon et al., 2009) - perhaps because the higher wages offered in private enterprises provide a better support a family. Membership to the Communist Party instead increases the likelihood of working for SOEs (Démurger et al., 2009).

\section{Methodology}

The empirical analysis of employment choice with a multitude of possible forms of ownerships is typically carried out in the context of multinomial logit (MNL)

\footnotetext{
${ }^{4}$ For example, SOEs were granted greater autonomy in hiring workers and their workers were allowed to enter into collective and newly-recognized private enterprises since 1980. A more flexible wage setting system was implemented in 1996, to include a fixed component (guding), covering the basic wage and housing, pension, medical, and unemployment benefits, and a variable portion (huo), which reflected an individual's productivity and an enterprise's profitability. Enterprises were permitted to set their internal wage structure within the confine of the overall wage budget established by the government.
} 
models, whereby the utility that a rural migrant $i$ chooses a type of enterprises $j$ is given by the expression:

$$
U_{i j}=x_{i}^{\prime} \beta_{j}+\mu_{i j}
$$

where $x_{i}$ is a $K \times 1$ vector of explanatory variables indicating characteristics of individual $i, \beta_{j}$ is a $K \times 1$ coefficient vector for choosing $j$, and $\mu_{i j}$ is error terms. If all error terms $\mu_{i j}$ are mutually independent with a Gumbel distribution (McFadden, 1973), the probability of a rural migrant $i$ choosing enterprise type $j$ can be expressed by:

$$
P_{i j}=P\left(y_{i}=\text { enterprise }_{j}\right)=\frac{\exp \left(x_{i}^{\prime} \beta_{j}\right)}{\sum_{k=1}^{m} \exp \left(x_{i}^{\prime} \beta_{k}\right)} \quad i=1, \ldots N ; j=1, \ldots, m
$$

where the coefficient vector for the first choice, $\beta_{1}$, is a null vector by normalisation; $N$ is the sample size of rural migrants; $m$ is the number of types of enterprise; and $x_{i}$ is a set of individual variables affecting the employment choice.

Since migrants are not a random sample of the population, their employment choice second is determined by their individual characteristics. The empirical literature typically adjusts this potential source of selectivity bias with some form of control function, in the form of a predicted probability to migrate or the additional utility associated with it (e.g. Hoffman \& Duncan, 1988; Shaw \& Ozog, 1999; Sartori, 2003). In either case, the inclusion of a control function within a MNL approach faces challenges in the consistent estimate of the correction's standard errors. Furthermore, the MNL assumes that the set of choices upon which an individual decides are statistically independent from each other. This may be plausible for 'substantial' choices (e.g. whether or not to migrate) but perhaps less when faced with other 
alternatives (e.g. working in a wholly-owned subsidiary of foreign company or in a Chinese-foreign joint-venture).

An alternative approach to the simultaneous estimation of an individual choice and a control function is the explicit modelling of the decisions to migrate and to choose an employer as a two-stage process within a nested multinomial logit (NMNL). In the first stage of the NMNL, workers decide on whether or not to migrate. In the second stage they choose one among various types of employers. Importantly, the NMNL model enables one to explicitly test whether or not the decision to migrate is correlated with that about which employer to choose: this is done by checking whether the inclusive value parameter ('IV') that corresponds to the expected value of the utility of individual $i$ obtained from the alternatives in a given nest, equals unity.

The NMNL approach has the additional advantage of avoiding the potential complications of selection models when the dependent variable of the selection equation contains multi-discrete values (e.g. Mallar, 1977; Wooldridge, 2007).

The NMNL preserves the assumption of IIA between the migration and nonmigration nests, while the IIA is relaxed among the eight nesting employment alternatives, which are depicted in Figure 1. The upper-level of Figure 1 shows a migration nest and a non-migration nest, both of which are built by aggregating migrant and non-migrant data. The bottom-level is composed of eight ownership enterprises that are clustered into the corresponding nest: private enterprises, SOEs, UCEs, and JVs are clustered into the migration nest. The same typology of four enterprises appears in the non-migration nest.

The utility level that a rural individual $i$ chooses a type of enterprise $j$ can be modelled as: 


$$
\begin{gathered}
U_{i, m j}=V_{i, m j}+\mu_{i, m j} \\
V_{i, m j}=\alpha_{m j}+X_{i, m j}^{\prime} \beta+Z_{i}^{\prime} \gamma_{m j}
\end{gathered}
$$

where $U_{i j}$ contains a deterministic part $V_{i j}$ and a stochastic part $\mu_{i j} . \alpha_{j}$ are alternativespecific constants; the vector $X_{i j}$ includes variables that vary both over choices and individuals; the vector $Z_{i}$ refers to individual-specific variables that describe characteristics of the decision maker.

Figure 1. Model nesting structure (simultaneous decision-making process)

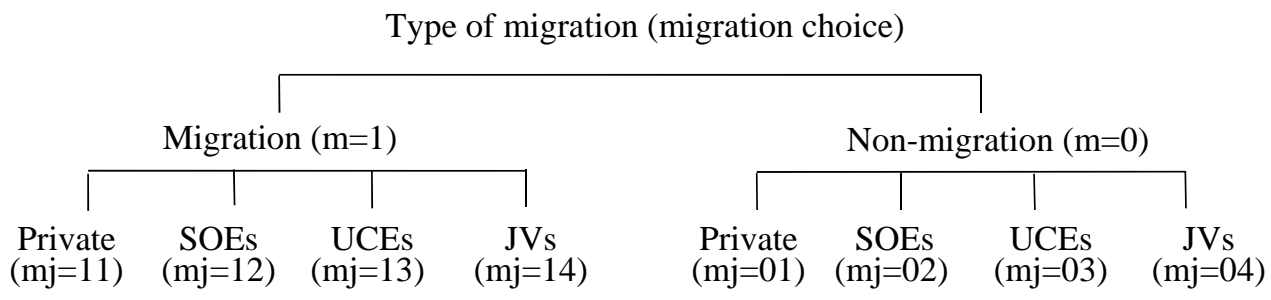

The probability of individual $i$ choosing alternative $j, P\left(y_{i}=j\right)$, is equal to the product of the probability to choose some alternatives in nest $B(j), P\left\{y_{i} \in B(j)\right\}$, and the conditional probability to choose exactly alternative $j$ given some alternatives in the same nest $B(j), P\left\{y_{i}=j \mid y_{i} \in B(j)\right\}$, hence:

$$
P_{i j}=P\left(y_{i}=j\right)=P\left\{y_{i}=j \mid y_{i} \in B(j)\right\} \cdot P\left\{y_{i} \in B(j)\right\}
$$

where the number of nests is set at 2: one for migration and another for non-migration.

Equation (5) can be re-written as:

$$
P_{i j}=\frac{e^{V_{i j} / \tau(j)}}{\sum_{k \in B(j)} e^{V_{i j} / \tau(j)}} \times \frac{e^{\tau(j) I V(j)}}{\sum_{m=1}^{M} e^{\tau_{m} I V_{m}}}
$$

where $\tau$ is called the dissimilarity parameter and represents the mutual correlation of error terms of all alternatives within a nest. When all $\tau_{m}$ lie in the unit interval the 
decision makers (i.e. rural workers) are assumed to choose the alternative among the eight types of enterprises from which they derive the highest utility (random utility maximization of nested logit - RUMNL). The parameter $I V$ is called inclusive value or the log sum, and is a rescaled measure of the attractiveness of the nest $B(j), I V_{m}=$ $\ln \sum_{k \in B_{m}} e^{V_{i k} / \tau_{m}}$

The independent variables in the choice equation consist of individual-specific and alternative-specific variables (i.e. wage, working hours/day, and pension benefits). The individual-specific variables are directly observed, while the individual- and choice-varying variables, such as wage, are weighted by the average value of the observations belonging to each of the 48 cells (each representing 8 types of ownership enterprises for migration and non-migration and 6 different levels of qualifications). The 6 different levels of qualifications are constructed by 3 educational levels (junior and below, senior, college and above), and 2 categories of working experience: up to 7 and more than 7 years (this is dictated by the distribution of this variable). The educational levels and working experience are included because of their potential roles in determining wages attainments (Zhao, 2001; Giulietti et al., 2012). In a similar way, a matrix comprising of 133 rows (19 provinces $\times 7$ industries) and 8 columns of ownership enterprises is built for calculating working hours, and a matrix of 7 industries and 8 types of enterprises is used for estimating pension benefits.

\section{Data and characteristics of samples}

The data used is drawn from the China Household Income Project (CHIP) conducted by the Institute of Economics, Chinese Academy of Social Sciences, with assistance from the Asian Development Bank and the Ford Foundation. The samples

were selected from significantly larger samples drawn by National Bureau of 
Statistics of China (NBSC). Only the cross-section data for 1995 and 2002 are used, as these were publicly available. ${ }^{5}$

The CHIP surveys feature separate samples for urban and rural China, and accordingly they are generally divided into a rural dataset and an urban dataset. The rural dataset covers all 28 provinces except Xinjiang and Tibet. The urban dataset contains 11 representative provinces: Beijing, Shanxi, Liaoning, Jiangsu, Anhui, Henan, Hubei, Guangdong, Yunnan, Gansu, and Sichuan. Each of the dataset further includes a household survey and an individual survey. There are a total of 1,505 and 5,327 rural-urban migrants in CHIP 1995 and 2002, respectively. The survey also covers a large scale of variables to reflect the socioeconomic characteristics of the labour market and the demographic information, migration history, family situation before leaving the home village of rural labour, rural migrants, permanent migrants, and urban residents.

SOEs, in the official definition, denote those enterprises whose assets are owned or shares are controlled by the state. In the CHIP data, SOEs refer to stateowned enterprises or institutions ${ }^{6}$ in 1995 , while SOEs are divided into those at the central/provincial level, those at the local level, and state share-holding enterprises in 2002. Non-SOEs are adjusted to be categorized into following three groups:

$$
\begin{aligned}
& \text { UCEs, which denote enterprises affiliated with a local government } \\
& \text { under a municipality or a county. Compared with SOEs, UCEs are } \\
& \text { less government-supported and more business-oriented in that they } \\
& \text { are typically subject to more budget constraints and are responsible }
\end{aligned}
$$

\footnotetext{
${ }^{5}$ CHIP 2007 is currently not released publicly.

${ }^{6}$ Although the public institutions were classified into SOEs in CHIP 1995, their number is comparatively small to the total number of SOEs and this classification has little influence on our empirical analyses.
} 
for their own profits and loss (Qian \& Xu, 1993).

(2)

Wholly owned non-SOEs (hereinafter called private enterprises). They consist of urban private enterprises which hire more than seven employees each, urban self-employed enterprises which hire fewer than seven employees each, and foreign enterprises.

(3) Sino-foreign joint venture companies which are shared by public and foreign capital, and other share-holding companies (e.g. Sinoforeign cooperative companies) which are owned jointly by Chinese entities (e.g. offering factory buildings and equipment) and foreign entities (e.g. providing technology).

Table 1 presents the employment percentage of rural labour, rural migrant workers, permanent migrants and urbanites in four types of enterprises - SOEs, UCEs, private and JVs. Note that rural labour refers to those who live in rural areas have rural-hukou, and engage in non-agricultural jobs. In contrast, permanent migrants denote rural migrants who have owned urban-hukou since 1978. Permanent migrants and urbanites are mainly employed in SOEs, whereas rural migrant workers and rural labour primarily work in private enterprises. From 1995 to 2002, the share of rural migrants and rural labour working in private enterprises doubled from about $42 \%$ to $84 \%$, and from $37 \%$ to $77 \%$, respectively. In contrast, the employment share of permanent migrants and urbanites in SOEs declined by about 30\%. The increased percentage in private enterprises contributes most to reducing the unemployment rate of rural migrants from $5.6 \%$ to $1.5 \%$, while the decline in SOEs seems to be the main reason for a rising unemployment rate among permanent migrants and urban residents. These data are likely to indicate the pivotal role of non-SOEs in recruiting 
rural migrants.

Table 2 presents summary statistics of rural migrant workers in the four types of enterprises. Compared with those in 1995, migrants in 2002 tend to have an older age (25 vs. 34 years old), higher proportion of married people (39\% vs. 89\%), a more balanced gender ratio (male/female: 7/3 vs. 5/5), and higher levels of education (senior and above educational levels: $28 \%$ vs. 16\%). On the other hand, educational levels are different in the four types of enterprises. Rural migrants with high educational levels ( $>=$ senior) are more willing to work in SOEs in 1995, while their first choice becomes JVs enterprises in 2002. In addition, the average wages in the four types of enterprises are not significantly different in 1995, but they are generally larger in non-SOEs than in SOEs in 2002 (e.g. 819 yuan in private enterprises vs. 604 yuan in SOEs).

The data also show that there is a larger provision of pensions in 2002, especially in SOEs (15\%) and JVs (16\%). However, the percentage is relatively low, and the official explanation is that rural migrants have been allocated access to farm land in their rural home towns, with improved welfare rights and security covered by the entitlement to the use of land (Song \& Appleton, 2008).

In 1995, the majority of rural migrant workers in both SOEs and non-SOEs are employed in manufacturing ( $>40 \%$ ), while a large proportion of UCEs workers are distributed in construction (49\%). In 2002, the largest proportion of rural migrants in SOEs and UCEs work in social services (>30\%); $55 \%$ of rural migrants in private enterprises engage in wholesale, retail and food services (WRF), and 34\% in JVs in the manufacturing sector.

\section{Empirical results}


Both MNL and NMNL estimates are presented. Table 3 reports the estimation results obtained from the MNL model. Age is positively related to employment in SOEs: a one-year increase in age increases the odds ratio of employment in SOEs by $0.0014(p<0.01)$. Older migrants appear strongly pulled into SOEs due to shorter working hours, less intensive work strength and greater job security. A similar result emerges for health, as the odds ratio of employment in SOEs is 1.8 times higher $\left(=\exp ^{0.5678}\right)$ for the poor health than for healthy workers. Educated workers also prefer to work in SOEs. Each additional year of schooling significantly increases the likelihood of participation in SOEs by $0.0038(p<0.01)$. This is consistent with previous studies (Wang, 2005; Démurger et al., 2009), which indicate that the comprehensive benefits and job security associated with SOEs play an important role in educated migrants' employment choice.

Males, traditionally, are less likely to be non-SOEs workers in European countries and former state socialist countries (Bedi, 1998; Christofides \& Pashardes, 2002). China is also no exception (Zhao, 2001). The net odds of choosing SOEs are 1.4 times $\left(=\exp ^{0.3684}\right)$ for males than females in the urban labour market. Membership to the Communist Party of China (CPC) has a positive relationship with the probability of employment in SOEs $(+7.8 \%)$, implying that political capital maintains an important influence on SOEs’ employment in contemporary China.

Concerning the industry dummies, SOEs workers have an obvious propensity for engaging in social services, while workers in UCEs and JVs work predominantly construction and manufacturing, respectively. The odds ratio for engaging in social services, construction, and manufacturing are $9.5\left(=\exp ^{2.2506}\right), 6.6\left(=\exp ^{1.8858}\right)$, and 6 times $\left(=\exp ^{1.7838}\right)$ higher than those estimated for wholesale/retail/food services. 
Rural migrants emerge as having a strong preference for private enterprises in 2002 compared to 1995. This result is primarily driven by wage incentives despite longer working hours. Compared to private enterprises, the wage increases 1000 yuan per month, the probability of joining in SOEs decreases by $0.1(p<0.01)$, implying that monetary incentive do matter. Similar results are also observed in UCEs and jointventure/other enterprises, when judged by the signs of the estimated coefficients.

Table 4 reports the results obtained from the NMNL for rural migrants, where migration and choice equations are estimated simultaneously. The LR test for IIA clearly rejects the null of the IV parameter equalling unity, while the dissimilarity parameter $\tau_{\text {migrate }}$ is within the unit interval. This corresponds to a correlation of error terms of about 0.8748, implying that unobserved factors that lead rural individuals to migrate also affect the choice of employment. Results also show that all the parameters $\tau_{m}$ lie in the unit interval, suggesting that the fitted NMNL model consistent with random utility maximization (RUMNL).

The estimates of migration, corrected for the selectivity bias, reveal that although individual characteristics are broadly similar to those in Table 3, there are important differences. Married migrants are less likely to choose SOEs than private enterprises (the reference group), as the odds ratio of choosing SOEs reduces by $38 \%$ for the married. Highly educated migrants have a higher propensity for employment in SOEs than the one reported in Table 3. Each additional year of schooling significantly increases the probability of choosing SOEs employment by $11.4 \%$. Formal schooling also raises the probability of working in JVs (+9.2\%), perhaps due to higher earnings and more opportunities to learn and promotion. 
Wage and pension benefits are statistically significant and positive $(p<0.01)$, though larger for the latter, suggesting that in choosing the employer the availability and size of the future pension has a stronger relevance than a high wage. This may be related to the fact that the number of working hours is also a positive determinant of the employment choice. Rural migrants are more likely to go into either type of enterprise which can let them work more than 1.5 hour per day. The possible reason is that longer working hours lead to higher earnings, which in turn increase migrants' employment, as shown in previous studies (Portes \& Zhou, 1996; Chen et al., 2005). In this case, longer working hours can be characterized as a "necessity” rather than "unfair treatments" for rural migrants. This is contrary to the interpretation of some qualitative studies (e.g. Lu, 2003; Wei \& Han, 2006; Wong et al., 2007), which view long working hours as a form of discrimination against rural migrants working in the cities.

The coefficient estimates for non-migrants are reported in Table 5. Males appear less likely to choose non-SOEs in rural areas, but prefer SOEs in urban areas. Older workers are more likely to work for SOEs - net odds ratio of employment in SOEs is 1.1 times $\left(=\exp ^{0.0549}\right)$. A similar result arises for married individuals, as they prefer to work in local UCEs. These results confirm the findings illustrated by Wei and Han (2006), who portray a rural China where older and married workers looking after children, house and land, prefer to work for enterprises that have less demanding jobs in terms of workload and shorter working hours.

Highly educated workers are more likely to work in SOEs, as per Zhu (2002). Senior secondary level increases the probability of migration by 1.179, probably as it enables one to look for better employment opportunities. The high employment rate in SOEs suggests that wages are not the only criterion which migrants consider in the 
choice of employment. Comprehensive benefits and job security also play a (likely more) important role.

\section{Conclusions and implications}

Overall, the determinants of employment choice of rural migrants are different when considering the effects of the migration decision in the context of NMNL. The main differences arise from wage, working hours/day, and pension benefit, which have significant and positive influence on the choice. Longer working hours can be characterized as a "necessity” rather than "unfair treatments" for rural migrants. To increase earnings, migrants appear willing to work longer hours to compensate for low hourly earnings, and therefore, they less concern about work environment and work strength. Both higher-paid wages and more pension benefit are major determinants to increase the employment rate of SOEs and non-SOEs. Of these, pension benefits have larger impact than high-paid wages in increasing the employment probability for both types of enterprises.

Our results broaden the perspective on employment choice across different ownership enterprises and indicate that even though several-decades-long economic reforms have been implemented in China, institutional barriers (e.g. the hukou system) and labour market constraints (e.g. the government-controlled operation mechanisms in SOEs) still play powerful roles in influencing the employment choice of rural migrants. 


\section{References}

Adamchik, V. A. \& Bedi, A. S. 2000. Wage differentials between the public and the private sectors: evidence from an economy in transition. Labour Economics, 7, 203-224.

Bedi, A. S. 1998. Sector choice, multiple job holding and wage differentials: Evidence from Poland. Journal of Development Studies, 35, 162-179.

Brooks, R. \& Tao, R. 2003. China's labour market performance and challenges. IMF Working Paper WP/03/210. Washington, DC, Estados Unidos: Fondo Monetario Internacional.

Cai, F. 2001. Institutional barriers in two processes of rural Labour migration in China. Working Paper Series No. 9. Beijing: Institute of Population Studies, Chinese Academy of Social Sciences.

Chen, Y., Démurger, S. \& Fournier, M. 2005. Earnings differentials and ownership structure in Chinese enterprises. Economic Development and Cultural Change, 53, 933-958.

Chow, H. S. \& Ngo, I.-Y. 2002. Gender differences in job attribute preferences and job choice of university students in China. Journal of Applied Business Research, 18, 15-25.

Christofides, L. N. \& Pashardes, P. 2002. Self/paid-employment, public/private sector selection, and wage differentials. Labour Economics, 9, 737-762.

Démurger, S., Gurgand, M., Li, S. \& Yue, X. 2009. Migrants as second-class workers in urban China? A decomposition analysis. Journal of Comparative Economics, 37, 610-628.

Dong, K. \& Ye, X. 2003. Social security system reform in China. China Economic Review, 14, 417425.

Dong, X.-Y. \& Bowles, P. 2002. Segmentation and discrimination in China's emerging industrial labour market. China Economic Review, 13, 170-196.

Du, Y., Park, A. \& Wang, S. 2005. Migration and rural poverty in China. Journal of Comparative Economics, 33, 688-709.

Fan, C. C. 2001. Migration and labor-market returns in urban China: Results from a recent survey in Guangzhou. Environment and Planning A, 33, 479-508.

Fu, Y. \& Gabriel, S. A. 2001. Transitions to private employment: earnings determination, worker employment preferences, and job turnover in urban China. University of Southern California, Marshall School of Business Working Paper. http://papers.ssrn.com.

Gagnon, J., Xenogiani, T. \& Xing, C. 2009. Are all migrants really worse off in urban labour markets? New empirical evidence from China. IARIW-SAIM Conference Working paper 278.

Giulietti, C., Ning, G. \& Zimmermann, F. K. 2012. Self-employment of rural-to-urban migrants in China. International Journal of Manpower, 33, 96-117.

Goodkind, D. \& West, L. A. 2002. China's floating population: Definitions, data and recent findings. Urban Studies (Routledge), 39, 2237-2250.

Greene, W. H. 2003. Econometric analysis, Fifth Edition, Upper Saddle River, NJ: Prentice hall New Jersey.

Gu, E. 2001. Beyond the property rights approach: Welfare policy and the reform of state-owned enterprises in China. Development and Change, 32, 129-150. 
Hare, D. 1999. 'Push' versus 'pull' factors in migration outflows and returns: Determinants of migration status and spell duration among China's rural population. Journal of Development Studies, 35, 45-72.

Harris, J. R. \& Todaro, M. P. 1970. Migration, unemployment and development: A two-sector analysis. The American Economic Review, 60, 126-142.

Heiss, F. 2002. Structural choice analysis with nested logit models. The Stata Journal, 2, 227-252.

Hoffman, S. D. \& Duncan, G. J. 1988. A comparison of choice-based multinomial and nested logit models: The family structure and welfare use decisions of divorced or separated women. The Journal of Human Resources, 23, 550-562.

Johnson, D. G. 2002. Can agricultural labour adjustment occur primarily through creation of rural nonfarm jobs in China? Urban Studies 39, 2163-2174.

Knight, J. \& Li, S. 2005. Wages, firm profitability and labor market segmentation in urban China. China Economic Review, 16, 205-228.

Knight, J., Song, L. \& Huaibin, J. 1999. Chinese rural migrants in urban enterprises: three perspectives. Journal of Development Studies, 35, 73-104.

Lin, J. Y. 1988. The household responsibility system in China's agricultural reform: A theoretical and empirical Study. Economic Development and Cultural Change, 36, S199-S224.

Lu, X. 2003. Fundamentally solve the issue of rural migrant workers. Theory and Practice of SEZs, 7, 31-36 (in Chinese).

Lu, Z. \& Song, S. 2006. Rural-urban migration and wage determination: The case of Tianjin, China. China Economic Review, 17, 337-345.

Mallar, C. D. 1977. The estimation of simultaneous probability models. Econometrica, 45, 1717-1722.

Mcfadden, D. 1973. Conditional logit analysis of qualitative choice behavior. Frontiers in Econometrics, 105-142.

Miyamoto, K. \& Liu, H. 2004. Sector choice and wage determinants: Evidence from urban China. Journal of Economics, Business and Law, 6, 27-43.

Portes, A. \& Zhou, M. 1996. Self-employment and the earnings of immigrants. American Sociological Review, 61, 219-230.

Qian, Y. \& Xu, C. 1993. Why China's economic reforms differ: The M form hierarchy and entry/expansion of the non-state sector. Economics of Transition, 1, 135-170.

Roberts, K. D. 2001. The determinants of job choice by rural labour migrants in Shanghai. China Economic Review, 12, 15-39.

Rozelle, S., Guo, L., Shen, M., Giles, J. \& Low, T. Y. 1997. Poverty, networks, institution, or education: Testing among competing hypotheses on the determinants of migration in China. Paper presented at the Annual Meetings of Association for Asian Studies, Chicago, Illinois. 13-16.

Sartori, A. E. 2003. An estimator for some binary-outcome selection models without exclusion restrictions. Political Analysis, 11, 111-138. 
Seeborg, M., Jin, Z. \& Zhu, Y. 2000. The new rural-urban labor mobility in China: Causes and implications. Journal of Socio-Economics, 29, 39-56.

Shaw, W. D. \& Ozog, M. 1999. Modeling overnight recreation trip choice: Application of a repeated nested multinomial logit model. Environmental and Resource Economics, 13, 397-414.

Song, L. \& Appleton, S. 2008. Social protection and migration in China: What can protect migrants from economic uncertainty? IZA Discussion Papers No. 3594, Bonn.

Todaro, M. P. 1969. A model of labour migration and urban unemployment in less developed countries. The American Economic Review, 59, 138-148.

Wang, M. 2005. Employment opportunities and wage gaps in the urban labour market: A study of the employment and wages of migrant labour. Journal of China Social Science, 5, 36-46 (in Chinese).

Wei, L. \& Han, C. 2006. The research report of rural migrant workers in China, presented by Project Team of Research Office of the State Council, Beijing, Chinese Yanshi Press (in Chinese).

Wong, D. F. K., Li, C. Y. \& Song, H. X. 2007. Rural migrant workers in urban China: Living a marginalized life. International Journal of Social Welfare, 16, 32-40.

Wooldridge, J. 2007. What's new in econometrics? Control functions and related methods. NBER Summer Institute.

Yueh, L. Y. 2004. Wage reforms in China during the 1990s. Asian Economic Journal, 18, 149-164.

Zhang, D. \& Meng, X. 2007. Assimilation or disassimilation?: The labour market performance of rural migrants in Chinese cities. 6th Conference on Chinese Economy, CERDI-IDREC.

Zhang, X. \& Li, G. 2003. Does guanxi matter to nonfarm employment? Journal of Comparative Economics, 31, 315-331.

Zhang, Z. 2004. Sectoral segmentation of labour markets and labour mobility. Population Science of China, 2, 45-52 (in Chinese).

Zhao, Y. 1997. Rural labour migration and the role of education. Economic Research, 2, 37-42 (in Chinese).

Zhao, Y. 1999a. Labour migration and earnings differences: The case of rural China. Economic Development and Cultural Change, 47, 767-782.

Zhao, Y. 1999b. Leaving the countryside: Rural-to-urban migration decisions in China. The American Economic Review, 89, 281-286.

Zhao, Y. 2001. Foreign direct investment and relative wages: The case of China. China Economic Review, 12, 40-57.

Zhao, Y. 2002. Earnings differentials between state and non-state enterprises in urban China. Pacific Economic Review, 7, 181-197.

Zhao, Y. 2003. The role of migrant networks in labour migration: The case of China. Contemporary Economic Policy, 21, 500-511.

Zhu, N. 2002. The impacts of income gaps on migration decisions in China. China Economic Review, $13,213-230$. 
Table 1. Employment percentage in different ownership enterprises

\begin{tabular}{rrcccc}
\hline & & Rural labour & Rural migrants & Permanent workers & Urbanites \\
\hline \multirow{4}{*}{1995 SOEs } & 14.50 & 10.31 & 76.78 & 81.51 \\
Private & 10.35 & 20.12 & 16.84 & 15.37 \\
& 36.95 & 41.24 & 3.65 & 1.95 \\
& Joint-venture/other & 38.20 & 28.32 & 2.74 & 1.17 \\
Total & 100 & 100 & 100 & 100 \\
& Number of Obs. & 3,662 & 805 & 1,645 & 11,966 \\
& Unemployment & 1.61 & 5.58 & 1.20 & 0.87 \\
\hline SOEs & 8.65 & 8.85 & 53.74 & 53.14 \\
UCEs & 11.56 & 4.62 & 10.39 & 10.81 \\
& Private & 77.06 & 83.94 & 22.90 & 21.41 \\
& Joint-venture/other & 2.73 & 2.59 & 12.98 & 14.64 \\
& Total & 100 & 100 & 100 & 100 \\
& Number of Obs. & 6,669 & 2,621 & 1,271 & 6,515 \\
& Unemployment & 1.81 & 1.46 & 2.59 & 3.35 \\
\hline
\end{tabular}

Note: Observations denote the number of working people without the unemployed. Unemployment in urbanites includes the laid-off (xiagang).

Table 2. Summary statistics of rural migrant workers in 1995 and 2002

\begin{tabular}{|c|c|c|c|c|c|c|c|c|}
\hline & \multicolumn{4}{|c|}{1995} & \multicolumn{4}{|c|}{2002} \\
\hline & SOEs & UCEs & Private & Joint & SOEs & UCEs & Private & Joint \\
\hline Age & 27.45 & 25.88 & 24.75 & 24.49 & 35.89 & 33.85 & 34.47 & 32.31 \\
\hline Married (\%) & 43.68 & 40.23 & 38.50 & 32.59 & 86.83 & 93.44 & 91.01 & 83.12 \\
\hline \multicolumn{9}{|l|}{ Gender (\%) } \\
\hline male & 72.41 & 80.68 & 62.73 & 60.37 & 66.67 & 50.00 & 56.10 & 53.25 \\
\hline female & 27.59 & 19.32 & 37.27 & 39.63 & 33.33 & 50.00 & 43.90 & 46.75 \\
\hline \multicolumn{9}{|l|}{ Education (\%) } \\
\hline College \& above & 1.15 & 0 & 0.26 & 0 & 6.17 & 1.61 & 1.24 & 14.29 \\
\hline Senior & 24.14 & 14.77 & 10.00 & 13.70 & 23.05 & 18.55 & 15.68 & 29.87 \\
\hline Junior & 58.62 & 61.93 & 60.53 & 57.78 & 43.62 & 50.00 & 51.63 & 37.66 \\
\hline Elementary\& below & 16.09 & 23.30 & 29.21 & 28.52 & 27.16 & 29.84 & 31.45 & 18.18 \\
\hline Wage (yuan/month) & 474.45 & 418.33 & 467.94 & 492.7 & 604.46 & 632.59 & 819.38 & 766.45 \\
\hline experience (year) & 3.31 & 2.14 & 1.95 & 2.24 & 6.82 & 6.99 & 7.21 & 6.22 \\
\hline Pension (\%) & 1.15 & 0.57 & 0 & 0.37 & 14.71 & 10.26 & 3.46 & 15.58 \\
\hline Working days/week & 5.79 & 6.11 & 6.27 & 6.07 & 6.36 & 6.46 & 6.75 & 6.14 \\
\hline Working hours/day & 8.05 & 8.52 & 9.20 & 9.00 & 9.29 & 9.25 & 10.46 & 9.05 \\
\hline \multicolumn{9}{|c|}{ Industrial distribution (\%) } \\
\hline ILEP/other & 17.50 & 8.22 & 10.01 & 11.76 & 12.55 & 11.38 & 8.80 & 22.00 \\
\hline Manufacturing & 50.00 & 33.54 & 49.81 & 55.20 & 15.90 & 15.45 & 9.38 & 34.21 \\
\hline Construction & 15.00 & 48.73 & 23.03 & 21.27 & 5.02 & 7.32 & 4.22 & 1.32 \\
\hline$W R F$ & 11.25 & 5.70 & 19.70 & 8.14 & 12.97 & 21.14 & 55.45 & 23.05 \\
\hline Social services & 6.25 & 3.80 & 9.09 & 3.62 & 53.55 & 44.71 & 22.14 & 18.42 \\
\hline
\end{tabular}

Note: ILEP denotes mining, geological survey and prospecting; transportation, communications, posts and telecommunications; materials supply and marketing, warehousing; finance and insurance; real estate. Social services includes public utilities; personal services or consulting services; public health, sports and social welfare; education, culture, arts and broadcasting; scientific and technical services; party, government or social organization. WRF denotes wholesale/retail/food services. 
Table 3. Multinomial logit model: Pooled two cross-sections (1995 and 2002)

\begin{tabular}{|c|c|c|c|c|c|c|}
\hline & \multicolumn{2}{|c|}{ SOEs } & \multicolumn{2}{|c|}{ UCEs } & \multicolumn{2}{|c|}{ JVs } \\
\hline Variables & Coefficient & Marginal & Coefficient & Marginal & Coefficient & Marginal \\
\hline Male & $\begin{array}{l}0.3684 * * \\
(0.1605)\end{array}$ & $\begin{array}{l}0.0187 * * \\
(0.0076)\end{array}$ & $\begin{array}{l}-0.2155 \\
(0.1947)\end{array}$ & $\begin{array}{l}-0.0093 \\
(0.0080)\end{array}$ & $\begin{array}{l}-0.2846 \\
(0.2449)\end{array}$ & $\begin{array}{l}-0.0066 \\
(0.0056)\end{array}$ \\
\hline Age & $\begin{array}{l}0.0273^{* * * *} \\
(0.0099)\end{array}$ & $\begin{array}{l}0.0014 * * * \\
(0.0005)\end{array}$ & $\begin{array}{l}-0.0050 \\
(0.0136)\end{array}$ & $\begin{array}{l}-0.0003 \\
(0.0005)\end{array}$ & $\begin{array}{l}0.0001 \\
(0.0178)\end{array}$ & $\begin{array}{l}-0.0002 \\
(0.0006)\end{array}$ \\
\hline Married & $\begin{array}{l}-0.2354 \\
(0.2571)\end{array}$ & $\begin{array}{l}-0.0129 \\
(0.0148)\end{array}$ & $\begin{array}{l}0.4566 \\
(0.3396)\end{array}$ & $\begin{array}{l}0.0165 \\
(0.0096)\end{array}$ & $\begin{array}{l}-0.4674 \\
(0.3753)\end{array}$ & $\begin{array}{l}-0.0123 \\
(0.0116)\end{array}$ \\
\hline \multicolumn{7}{|c|}{ Member of CPC (reference: No) } \\
\hline Yes & $\begin{array}{l}1.0739 * * * \\
(0.3194)\end{array}$ & $\begin{array}{l}0.0784 * * \\
(0.0343)\end{array}$ & $\begin{array}{l}-0.5912 \\
(0.7506)\end{array}$ & $\begin{array}{l}-0.0222 \\
(0.0154)\end{array}$ & $\begin{array}{l}1.4652 * * * \\
(0.4645)\end{array}$ & $\begin{array}{l}0.0593 * * \\
(0.0327)\end{array}$ \\
\hline Years of schooling & $\begin{array}{l}0.0803 * * * \\
(0.0306)\end{array}$ & $\begin{array}{l}0.0038 * * \\
(0.0015)\end{array}$ & $\begin{array}{l}0.0407 \\
(0.0376)\end{array}$ & $\begin{array}{l}0.0013 \\
(0.0015)\end{array}$ & $\begin{array}{l}0.1216 * * \\
(0.0498)\end{array}$ & $\begin{array}{l}0.0025^{* *} \\
(0.0011)\end{array}$ \\
\hline Health & $\begin{array}{l}-0.5678^{* * *} \\
(0.2096)\end{array}$ & $\begin{array}{l}-0.0342^{* *} \\
(0.0151)\end{array}$ & $\begin{array}{l}-0.0905 \\
(0.2777)\end{array}$ & $\begin{array}{l}-0.0021 \\
(0.0114)\end{array}$ & $\begin{array}{l}-0.0353 \\
(0.3599)\end{array}$ & $\begin{array}{l}0.0001 \\
(0.0067)\end{array}$ \\
\hline \multicolumn{7}{|c|}{ Industries (reference: Wholesale/retail/food services) } \\
\hline Manufacturing & $\begin{array}{l}1.7915^{* * * *} \\
(0.2559)\end{array}$ & $\begin{array}{l}0.1387 * * * \\
(0.0307)\end{array}$ & $\begin{array}{l}1.3731^{* * *} \\
(0.2917)\end{array}$ & $\begin{array}{l}0.0649 * * * \\
(0.0227)\end{array}$ & $\begin{array}{l}1.7838 * * * \\
(0.3157)\end{array}$ & $\begin{array}{l}0.0588 * * * \\
(0.0185)\end{array}$ \\
\hline Social Services & $\begin{array}{l}2.2506 * * * \\
(0.2167)\end{array}$ & $\begin{array}{l}0.1812^{* * *} \\
(0.0233)\end{array}$ & $\begin{array}{l}1.5632 * * * \\
(0.2487)\end{array}$ & $\begin{array}{l}0.0719 * * * \\
(0.0167)\end{array}$ & $\begin{array}{l}0.5985^{*} \\
(0.3550)\end{array}$ & $\begin{array}{l}0.0061 \\
(0.0084)\end{array}$ \\
\hline ILEP/other & $\begin{array}{l}1.8048 * * * \\
(0.2708)\end{array}$ & $\begin{array}{l}0.1535^{* * *} \\
(0.0358)\end{array}$ & $\begin{array}{l}1.1244 * * * \\
(0.3434)\end{array}$ & $\begin{array}{l}0.0477 * * \\
(0.0244)\end{array}$ & $\begin{array}{l}1.4432 * * * \\
(0.3632)\end{array}$ & $\begin{array}{l}0.0413 * * \\
(0.0183)\end{array}$ \\
\hline Construction & $\begin{array}{l}0.9753 * * \\
(0.4211)\end{array}$ & $\begin{array}{l}0.0523 \\
(0.0365)\end{array}$ & $\begin{array}{l}1.8858 * * * \\
(0.3539)\end{array}$ & $\begin{array}{l}0.1573 * * * \\
(0.0493)\end{array}$ & $\begin{array}{l}0.0602 \\
(0.7712)\end{array}$ & $\begin{array}{l}-0.0041 \\
(0.0140)\end{array}$ \\
\hline \multicolumn{7}{|c|}{ Year (reference: 1995) } \\
\hline Year 2002 & $\begin{array}{l}-2.0510^{* * *} \\
(0.3247)\end{array}$ & $\begin{array}{l}-0.1519 * * * \\
(0.463)\end{array}$ & $\begin{array}{l}-2.5195 * * * \\
(0.3705)\end{array}$ & $\begin{array}{l}-0.2128^{* * *} \\
(0.0617)\end{array}$ & $\begin{array}{l}-1.8595 * * * \\
(0.4380)\end{array}$ & $\begin{array}{l}-0.0505^{* * *} \\
(0.0270)\end{array}$ \\
\hline Wage/month & $\begin{array}{l}-0.0011^{* * *} \\
(0.0002)\end{array}$ & $\begin{array}{l}-0.0001 * * * \\
(0.0001)\end{array}$ & $\begin{array}{l}-0.0003^{*} \\
(0.0002)\end{array}$ & $\begin{array}{l}-0.0001 \\
(0.0001)\end{array}$ & $\begin{array}{l}-0.0002 \\
(0.0002)\end{array}$ & $\begin{array}{l}-2.01 \mathrm{e}-06 \\
(0.0000)\end{array}$ \\
\hline Working hours/day & $\begin{array}{l}-0.2280 * * * \\
(0.0328)\end{array}$ & $\begin{array}{l}-0.0107^{* * *} \\
(0.0017)\end{array}$ & $\begin{array}{l}-0.1649 * * * \\
(0.0408)\end{array}$ & $\begin{array}{l}-0.0060 * * \\
(0.0016)\end{array}$ & $\begin{array}{l}-0.01817^{* * *} \\
(0.0513)\end{array}$ & $\begin{array}{l}-0.0036^{* *} \\
(0.0011)\end{array}$ \\
\hline pension & $\begin{array}{l}1.6335^{* * *} \\
(0.2810)\end{array}$ & $\begin{array}{l}0.1615^{* * * *} \\
(0.0398)\end{array}$ & $\begin{array}{l}1.1211^{* * *} \\
(0.3741)\end{array}$ & $\begin{array}{l}0.0499 * * \\
(0.0269)\end{array}$ & $\begin{array}{l}0.6713 \\
(0.4250)\end{array}$ & $\begin{array}{l}0.0509 \\
(0.0244)\end{array}$ \\
\hline Constant & $\begin{array}{l}0.1564 \\
(0.5603)\end{array}$ & & $\begin{array}{l}0.1756 \\
(0.6921)\end{array}$ & & $\begin{array}{l}-0.8636 \\
(0.8496)\end{array}$ & \\
\hline Pseudo $\mathrm{R}^{\wedge} 2$ & \multicolumn{6}{|c|}{0.1849} \\
\hline LR chi2 & \multicolumn{6}{|c|}{650.07} \\
\hline (p) & \multicolumn{6}{|c|}{0.0000} \\
\hline Number of Obs. & \multicolumn{6}{|c|}{2,647} \\
\hline Log likelihood & \multicolumn{6}{|c|}{-1432.6803} \\
\hline
\end{tabular}

Notes: Robust standard errors in parentheses. ${ }^{*} \mathrm{p}<0.1$; ${ }^{* *} \mathrm{p}<0.05$; ${ }^{* *} \mathrm{p}<0.01$. The reference category is private enterprises. 
Table 4. Nested multinomial logit model of migration: Pooled two cross-sections (1995 and 2002)

\begin{tabular}{|c|c|c|c|c|c|c|}
\hline \multicolumn{7}{|c|}{ Lower-level equation (private enterprises in urban areas $=$ reference category) } \\
\hline \multirow[b]{2}{*}{ Variables } & \multicolumn{2}{|c|}{ SOEs } & \multicolumn{2}{|c|}{ UCEs } & \multicolumn{2}{|c|}{ JVs } \\
\hline & Coefficient & Marginal & Coefficient & Marginal & Coefficient & Marginal \\
\hline Male & $\begin{array}{l}0.4357 * * * \\
(0.2873)\end{array}$ & $\begin{array}{l}0.0189 * * * \\
(0.0104)\end{array}$ & $\begin{array}{l}-0.6464 \\
(0.1631)\end{array}$ & $\begin{array}{l}-0.0122 \\
(0.0103)\end{array}$ & $\begin{array}{l}-0.7154 \\
(0.2112)\end{array}$ & $\begin{array}{l}-0.0404 \\
(0.0098)\end{array}$ \\
\hline Age & $\begin{array}{l}0.0527 * * * \\
(0.0162)\end{array}$ & $\begin{array}{l}0.0026 * * * \\
(0.0015)\end{array}$ & $\begin{array}{l}-0.0390 \\
(0.0386)\end{array}$ & $\begin{array}{l}-0.0003 \\
(0.0008)\end{array}$ & $\begin{array}{l}-0.0034 \\
(0.1052)\end{array}$ & $\begin{array}{l}-0.0003 \\
(0.0001)\end{array}$ \\
\hline Married & $\begin{array}{l}-0.4723^{* *} \\
(0.7986)\end{array}$ & $\begin{array}{l}-0.0139 * * \\
(0.0099)\end{array}$ & $\begin{array}{l}1.9455 \\
(1.9983)\end{array}$ & $\begin{array}{l}0.0081 \\
(0.0211)\end{array}$ & $\begin{array}{l}-0.6431 \\
(0.1838)\end{array}$ & $\begin{array}{l}-0.0044 \\
(0.0089)\end{array}$ \\
\hline \multicolumn{7}{|c|}{ Member of CPC (reference: No) } \\
\hline Yes & $\begin{array}{l}2.1439 * * * \\
(0.9470)\end{array}$ & $\begin{array}{l}0.1613^{* * *} \\
(0.0158)\end{array}$ & $\begin{array}{l}-1.0077 \\
(1.1184)\end{array}$ & $\begin{array}{l}-0.0488 \\
(0.0152)\end{array}$ & $\begin{array}{l}2.8503 * * * \\
(0.8074)\end{array}$ & $\begin{array}{l}0.1389 * * * \\
(0.0063)\end{array}$ \\
\hline Years of schooling & $\begin{array}{l}1.2785^{* * * *} \\
(0.3346)\end{array}$ & $\begin{array}{l}0.1141^{* * *} \\
(0.0015)\end{array}$ & $\begin{array}{l}0.1105 \\
(0.1365)\end{array}$ & $\begin{array}{l}0.1003 \\
(0.0023)\end{array}$ & $\begin{array}{l}1.1909 * * * \\
(0.5547)\end{array}$ & $\begin{array}{l}0.0924 * * * \\
(0.0010)\end{array}$ \\
\hline Health & $\begin{array}{l}-1.2799 * * * \\
(0.4130)\end{array}$ & $\begin{array}{l}-0.1167 * * \\
(0.0105)\end{array}$ & $\begin{array}{l}-0.1226 \\
(0.0906)\end{array}$ & $\begin{array}{l}0.0306 \\
(0.0215)\end{array}$ & $\begin{array}{l}1.1054 \\
(1.0045)\end{array}$ & $\begin{array}{l}0.1014 \\
(0.0079)\end{array}$ \\
\hline \multicolumn{7}{|c|}{ Industry dummy (reference: Wholesale/retail/food services) } \\
\hline Manufacturing & $\begin{array}{l}3.0275^{* * *} \\
(2.9911)\end{array}$ & $\begin{array}{l}0.1307 * * * \\
(0.0181)\end{array}$ & $\begin{array}{l}2.2830 * * * \\
(0.1304)\end{array}$ & $\begin{array}{l}0.1360^{* * *} \\
(0.0148)\end{array}$ & $\begin{array}{l}3.0590 * * * \\
(0.5636)\end{array}$ & $\begin{array}{l}0.1109 * * * \\
(0.0028)\end{array}$ \\
\hline Social Services & $\begin{array}{l}4.1462 * * * \\
(1.6794)\end{array}$ & $\begin{array}{l}0.2105^{* * *} \\
(0.0165)\end{array}$ & $\begin{array}{l}2.8549 * * * \\
(0.2440)\end{array}$ & $\begin{array}{l}0.0800^{* * *} \\
(0.0062)\end{array}$ & $\begin{array}{l}1.4495 \\
(0.6104)\end{array}$ & $\begin{array}{l}0.0082 \\
(0.0170)\end{array}$ \\
\hline ILEP/other & $\begin{array}{l}2.7288 * * * \\
(0.0008)\end{array}$ & $\begin{array}{l}0.1215^{* * *} \\
(0.0113)\end{array}$ & $\begin{array}{l}2.0212^{* *} \\
(0.4890)\end{array}$ & $\begin{array}{l}0.0925^{* *} \\
(0.0029)\end{array}$ & $\begin{array}{l}2.2317 * * \\
(0.8374)\end{array}$ & $\begin{array}{l}0.1036 * * \\
(0.0063)\end{array}$ \\
\hline Construction & $\begin{array}{l}1.8975 * * \\
(0.6237)\end{array}$ & $\begin{array}{l}0.1009 * * \\
(0.0044)\end{array}$ & $\begin{array}{l}3.0500 * * * \\
(1.3153)\end{array}$ & $\begin{array}{l}0.1194 * * * \\
(0.0362)\end{array}$ & $\begin{array}{l}1.0738 \\
(0.7712)\end{array}$ & $\begin{array}{l}0.0157 \\
(0.0148)\end{array}$ \\
\hline \multicolumn{7}{|l|}{ Year (reference: 1995) } \\
\hline Year 2002 & $\begin{array}{l}-2.7350 * * * \\
(0.3657)\end{array}$ & $\begin{array}{l}-0.1019 * * * \\
(0.0034)\end{array}$ & $\begin{array}{l}-2.8863 * * * \\
(0.1123)\end{array}$ & $\begin{array}{l}-0.0718^{* * *} \\
(0.0116)\end{array}$ & $\begin{array}{l}-2.2287 * * * \\
(0.2404)\end{array}$ & $\begin{array}{l}-0.0923 \text { *** } \\
(0.0001)\end{array}$ \\
\hline Wage/month & $\begin{array}{l}0.0029 * * * \\
(0.0002)\end{array}$ & $\begin{array}{l}0.0004 * * * \\
(0.0001)\end{array}$ & $\begin{array}{l}0.0029 * * \\
(0.0002)\end{array}$ & $\begin{array}{l}0.0004 * * \\
(0.0001)\end{array}$ & $\begin{array}{l}0.0029 * * \\
(0.0002)\end{array}$ & $\begin{array}{l}0.0004^{* *} \\
(0.0001)\end{array}$ \\
\hline Working hours/day & $\begin{array}{l}0.4698^{* * *} * \\
(0.0681)\end{array}$ & $\begin{array}{l}0.0049 * * * \\
(0.0002)\end{array}$ & $\begin{array}{l}0.4698 * * * \\
(0.0681)\end{array}$ & $\begin{array}{l}0.0049 * * * \\
(0.0002)\end{array}$ & $\begin{array}{l}0.4698 * * * \\
(0.0681)\end{array}$ & $\begin{array}{l}0.0049 * * * \\
(0.0002)\end{array}$ \\
\hline Pension & $\begin{array}{l}4.1452^{* * *} \\
(1.3741)\end{array}$ & $\begin{array}{l}0.2184^{* * *} \\
(0.0099)\end{array}$ & $\begin{array}{l}4.1452 * * * \\
(1.3741)\end{array}$ & $\begin{array}{l}0.2184^{* * *} \\
(0.0099)\end{array}$ & $\begin{array}{l}4.1452 * * * \\
(1.3741)\end{array}$ & $\begin{array}{l}0.2184 * * * \\
(0.0099)\end{array}$ \\
\hline Constant & $\begin{array}{l}2.1433 \\
(2.3122) \\
\end{array}$ & & $\begin{array}{l}2.1629 \\
(2.0199) \\
\end{array}$ & & $\begin{array}{l}-2.0324^{* *} \\
(2.5631)\end{array}$ & \\
\hline \multicolumn{7}{|c|}{ Upper-level equation (non-migration = reference category) } \\
\hline $\begin{array}{l}\begin{array}{l}\text { Non-agricultural work } \\
\text { experience }\end{array} \\
\end{array}$ & \multicolumn{6}{|c|}{$\begin{array}{l}0.0338 * * * \\
(0.0093)\end{array}$} \\
\hline \multicolumn{7}{|l|}{ dissimilarity parameters } \\
\hline tau-migrate & \multicolumn{6}{|c|}{0.8748} \\
\hline tau-non-migrate & \multicolumn{6}{|c|}{0.6285} \\
\hline LR test for IIA (tau $=1)$ & \multicolumn{6}{|c|}{$\operatorname{chi} 2(2)=681.73$, Prob $>$ chi2 $=0.0000$} \\
\hline Cases & \multicolumn{6}{|c|}{9,314} \\
\hline Wald chi2 & \multicolumn{6}{|c|}{781.34} \\
\hline$(\mathrm{P})$ & \multicolumn{6}{|c|}{0.0000} \\
\hline Log Likelihood & \multicolumn{6}{|c|}{-4043.9651} \\
\hline
\end{tabular}


Table 5. Nested multinomial logit model of non-migration: Pooled two cross-sections (1995 and 2002)

\begin{tabular}{|c|c|c|c|c|c|c|c|c|}
\hline \multicolumn{9}{|c|}{ Lower-level equation (private enterprises in urban areas = reference category) } \\
\hline & \multicolumn{2}{|c|}{ SOES } & \multicolumn{2}{|c|}{ UCEs } & \multicolumn{2}{|c|}{ Private } & \multicolumn{2}{|c|}{ JVs } \\
\hline Variables & Coefficient & Marginal & Coefficient & Marginal & Coefficient & Marginal & Coefficient & Marginal \\
\hline Male & $\begin{array}{l}0.0833 \\
(0.1091)\end{array}$ & $\begin{array}{l}0.0145 \\
(0.0109)\end{array}$ & $\begin{array}{l}-0.4087 * * * \\
(0.1025)\end{array}$ & $\begin{array}{l}-0.0401 * * * \\
(0.0107)\end{array}$ & $\begin{array}{l}-0.7800 * \\
(0.6063)\end{array}$ & $\begin{array}{l}-0.0306 * \\
(0.0162)\end{array}$ & $\begin{array}{l}-0.3743 * * \\
(0.1761)\end{array}$ & $\begin{array}{l}-0.0108 * * \\
(0.0049)\end{array}$ \\
\hline Age & $\begin{array}{l}0.0549 * * * \\
(0.0054)\end{array}$ & $\begin{array}{l}0.0028 * * * \\
(0.0006)\end{array}$ & $\begin{array}{l}0.0237 * * * \\
(0.0053)\end{array}$ & $\begin{array}{l}0.0021^{* * *} \\
(0.0005)\end{array}$ & $\begin{array}{l}-0.0361 \\
(0.0476)\end{array}$ & $\begin{array}{l}-0.0025 \\
(0.0018)\end{array}$ & $\begin{array}{l}-0.0641^{* * *} \\
(0.0166)\end{array}$ & $\begin{array}{l}-0.0020^{* *} \\
(0.0009)\end{array}$ \\
\hline Married & $\begin{array}{l}-0.0319 \\
(0.1345)\end{array}$ & $\begin{array}{l}-0.0105 \\
(0.0145)\end{array}$ & $\begin{array}{l}0.6836^{* * *} \\
(0.1493)\end{array}$ & $\begin{array}{l}0.0576^{* * *} \\
(0.0110)\end{array}$ & $\begin{array}{l}-0.5492 * * \\
(0.2244)\end{array}$ & $\begin{array}{l}-0.0418^{* *} \\
(0.0206)\end{array}$ & $\begin{array}{l}-0.3082 \\
(0.2648)\end{array}$ & $\begin{array}{l}-0.0054 \\
(0.0122)\end{array}$ \\
\hline \multicolumn{9}{|c|}{ Member of CPC (reference: No) } \\
\hline Yes & $\begin{array}{l}1.5432 * * * \\
(0.1409)\end{array}$ & $\begin{array}{l}0.0479 * * * \\
(0.0182)\end{array}$ & $\begin{array}{l}1.8393^{* * *} \\
(0.1444)\end{array}$ & $\begin{array}{l}0.0858 * * * \\
(0.0201)\end{array}$ & $\begin{array}{l}-2.0816^{* *} \\
(0.0246)\end{array}$ & $\begin{array}{l}-0.1388 * * * \\
(0.0265)\end{array}$ & $\begin{array}{l}1.5228 \\
(0.4504)\end{array}$ & $\begin{array}{l}0.0051 \\
(0.0135)\end{array}$ \\
\hline Years of schooling & $\begin{array}{l}0.1345^{* * * *} \\
(0.0190)\end{array}$ & $\begin{array}{l}0.0136^{* * *} \\
(0.0021)\end{array}$ & $\begin{array}{l}0.0322 * \\
(0.0187)\end{array}$ & $\begin{array}{l}0.0011 \\
(0.0017)\end{array}$ & $\begin{array}{l}-0.6444 * * * \\
(0.1518)\end{array}$ & $\begin{array}{l}-0.0160 * * * \\
(0.0030)\end{array}$ & $\begin{array}{l}-0.1115^{* * * *} \\
(0.0401)\end{array}$ & $\begin{array}{l}-0.0027 * * * \\
(0.0018)\end{array}$ \\
\hline Health & $\begin{array}{l}-0.1504 \\
(0.1489)\end{array}$ & $\begin{array}{l}-0.0161 \\
(0.0170)\end{array}$ & $\begin{array}{l}0.0263 \\
(0.1573)\end{array}$ & $\begin{array}{l}0.0050 \\
(0.0136)\end{array}$ & $\begin{array}{l}0.0925 \\
(0.8425)\end{array}$ & $\begin{array}{l}0.0179 \\
(0.0243)\end{array}$ & $\begin{array}{l}-0.4346 \\
(0.3474)\end{array}$ & $\begin{array}{l}-0.0068 \\
(0.0158)\end{array}$ \\
\hline \multicolumn{9}{|c|}{ Industry dummy (reference: Wholesale/retail/food services) } \\
\hline Manufacturing & $\begin{array}{l}-0.1704 \\
(0.1779)\end{array}$ & $\begin{array}{l}-0.0494 \\
(0.0181)\end{array}$ & $\begin{array}{l}2.0474 * * * \\
(0.2792)\end{array}$ & $\begin{array}{l}0.2158 * * * \\
(0.0382)\end{array}$ & $\begin{array}{l}-1.5342 * * * \\
(0.2437)\end{array}$ & $\begin{array}{l}-0.1956^{* * *} \\
(0.0492)\end{array}$ & $\begin{array}{l}2.0402^{* * * *} \\
(0.4608)\end{array}$ & $\begin{array}{l}0.0622^{* *} \\
(0.0292)\end{array}$ \\
\hline Social Services & $\begin{array}{l}3.0205^{* * *} \\
(0.1792)\end{array}$ & $\begin{array}{l}0.4314 * * * \\
(0.0499)\end{array}$ & $\begin{array}{l}2.2774 * * * \\
(0.3125)\end{array}$ & $\begin{array}{l}0.1471^{* * *} \\
(0.0507)\end{array}$ & $\begin{array}{l}-3.2665 * * * \\
(0.9904)\end{array}$ & $\begin{array}{l}-0.5830 * * * \\
(0.0321)\end{array}$ & $\begin{array}{l}1.5641 \\
(0.5974)\end{array}$ & $\begin{array}{l}0.0135 \\
(0.0045)\end{array}$ \\
\hline ILEP/other & $\begin{array}{l}1.0885^{* * *} \\
(0.1772)\end{array}$ & $\begin{array}{l}0.0808^{* * *} \\
(0.0286)\end{array}$ & $\begin{array}{l}1.8910 \\
(0.2914)\end{array}$ & $\begin{array}{l}0.2271 \\
(0.0549)\end{array}$ & $\begin{array}{l}-1.6446 * * * \\
(0.8067)\end{array}$ & $\begin{array}{l}-0.3257 * * * \\
(0.0434)\end{array}$ & $\begin{array}{l}1.4656 * * \\
(0.5177)\end{array}$ & $\begin{array}{l}0.0398 * * \\
(0.0179)\end{array}$ \\
\hline Construction & $\begin{array}{l}0.4596 * * \\
(0.1920)\end{array}$ & $\begin{array}{l}0.0349 \\
(0.0243)\end{array}$ & $\begin{array}{l}0.9793^{* * *} \\
(0.3124)\end{array}$ & $\begin{array}{l}0.1064 * * \\
(0.0444)\end{array}$ & $\begin{array}{l}-1.0180 * * * \\
(0.3173)\end{array}$ & $\begin{array}{l}-0.1373^{* * *} \\
(0.0431)\end{array}$ & $\begin{array}{l}-0.1385 \\
(0.7405)\end{array}$ & $\begin{array}{l}-0.0041 \\
(0.0118)\end{array}$ \\
\hline \multicolumn{9}{|l|}{ Year (reference: 1995) } \\
\hline Year 2002 & $\begin{array}{l}-6.1491^{* *} \\
(0.6407)\end{array}$ & $\begin{array}{l}-0.3644 * \\
(0.0157)\end{array}$ & $\begin{array}{l}-6.1068 * * \\
(0.5820)\end{array}$ & $\begin{array}{l}-0.1678 \\
(0.0132)\end{array}$ & $\begin{array}{l}6.2898 \\
(0.5567)\end{array}$ & $\begin{array}{l}0.0286 \\
(0.0099)\end{array}$ & $\begin{array}{l}-5.9715 \\
(0.5780)\end{array}$ & $\begin{array}{l}0.0030 \\
(0.0017)\end{array}$ \\
\hline Wage/month & $\begin{array}{l}0.0029 * * * \\
(0.0002)\end{array}$ & $\begin{array}{l}0.0004^{* * *} \\
(0.0001)\end{array}$ & $\begin{array}{l}0.0029 * * \\
(0.0002)\end{array}$ & $\begin{array}{l}0.0004 * * \\
(0.0001)\end{array}$ & $\begin{array}{l}0.0029 * * \\
(0.0002)\end{array}$ & $\begin{array}{l}0.0004^{* *} \\
(0.0001)\end{array}$ & $\begin{array}{l}0.0029 * * \\
(0.0002)\end{array}$ & $\begin{array}{l}0.0004 * * \\
(0.0001)\end{array}$ \\
\hline Working hours/day & $\begin{array}{l}0.4698 * * * \\
(0.0681)\end{array}$ & $\begin{array}{l}0.0049 * * * \\
(0.0002)\end{array}$ & $\begin{array}{l}0.4698 * * * \\
(0.0681)\end{array}$ & $\begin{array}{l}0.0049 * * * \\
(0.0002)\end{array}$ & $\begin{array}{l}0.4698^{* * *} \\
(0.0681)\end{array}$ & $\begin{array}{l}0.0049 * * * \\
(0.0002)\end{array}$ & $\begin{array}{l}0.4698 * * * \\
(0.0681)\end{array}$ & $\begin{array}{l}0.0049 * * * \\
(0.0002)\end{array}$ \\
\hline Pension & $\begin{array}{l}4.1452 * * * \\
(1.3741)\end{array}$ & $\begin{array}{l}0.2184 * * * \\
(0.0099)\end{array}$ & $\begin{array}{l}4.1452 * * * \\
(1.3741)\end{array}$ & $\begin{array}{l}0.2184 * * * \\
(0.0099)\end{array}$ & $\begin{array}{l}4.1452 * * * \\
(1.3741)\end{array}$ & $\begin{array}{l}0.2184 * * * \\
(0.0099)\end{array}$ & $\begin{array}{l}4.1452 * * * \\
(1.3741)\end{array}$ & $\begin{array}{l}0.2184 * * * \\
(0.0099)\end{array}$ \\
\hline Constant & $\begin{array}{l}-4.4052^{* * * *} \\
(0.4939)\end{array}$ & & $\begin{array}{l}-5.5664 * * * \\
(0.5574)\end{array}$ & & $\begin{array}{l}-3.6786^{* * * *} \\
(2.5724)\end{array}$ & & $\begin{array}{l}-4.7431^{* * *} \\
(1.5413)\end{array}$ & \\
\hline \multicolumn{9}{|c|}{ Upper-level equation (non-migration = reference category) } \\
\hline $\begin{array}{c}\text { Non-agricultural work } \\
\text { experience }\end{array}$ & \multicolumn{8}{|c|}{$\begin{array}{c}0.0338^{* * *} \\
(0.0093) \\
\end{array}$} \\
\hline \multicolumn{9}{|l|}{ dissimilarity parameters } \\
\hline tau-migrate & \multicolumn{8}{|c|}{0.8748} \\
\hline tau-non-migrate & \multicolumn{8}{|c|}{0.6285} \\
\hline LR test for IIA(tau = 1) & \multicolumn{8}{|c|}{$\operatorname{chi} 2(2)=681.73$, Prob $>$ chi $2=0.0000$} \\
\hline Cases & \multicolumn{8}{|c|}{9,314} \\
\hline Wald chi2 & \multicolumn{8}{|c|}{781.34} \\
\hline$(\mathrm{P})$ & \multicolumn{8}{|c|}{0.0000} \\
\hline Log Likelihood & \multicolumn{8}{|c|}{-4043.9651} \\
\hline
\end{tabular}




\section{Appendix}

Table A1. China’s policies on the reform of the hukou system since 1978

\begin{tabular}{|c|c|c|c|}
\hline Date & Document & Department & Main policies \\
\hline Dec, 1978 & $\begin{array}{l}\text { the Third Session of } \\
\text { the Eleventh Central } \\
\text { Committee of the } \\
\text { Party }\end{array}$ & $\begin{array}{c}\text { Chinese } \\
\text { Communist Party } \\
\text { Central } \\
\text { Committee(CCC } \\
\text { P) }\end{array}$ & $\begin{array}{l}\text { The central government announced the } \\
\text { reform of hukou system and planned to } \\
\text { make the adjustments for the reforming and } \\
\text { opening-up policy. }\end{array}$ \\
\hline 1980 & $\begin{array}{l}\text { Guidelines on } \\
\text { promoting } \\
\text { employment in cities }\end{array}$ & $\begin{array}{l}\text { CCCP and State } \\
\text { Council }\end{array}$ & $\begin{array}{l}\text { 1) Established and developed village } \\
\text { enterprises to absorb surplus rural labour; } \\
\text { 2) Sent RMWs back to villages. }\end{array}$ \\
\hline 1981 & $\begin{array}{l}\text { Decisions on seeking } \\
\text { ways to stimulate } \\
\text { economy and promote } \\
\text { employment in towns } \\
\text { and cities }\end{array}$ & $\begin{array}{l}\text { CCCP and State } \\
\text { Council }\end{array}$ & $\begin{array}{l}\text { 1) Strongly controlled enterprises over } \\
\text { recruiting RMWs; } \\
\text { 2) Sent RMWs back to villages; } \\
\text { 3) Prohibited the Labour Department } \\
\text { issuing documents for giving employment } \\
\text { permits to RMWs. }\end{array}$ \\
\hline 1981 & $\begin{array}{c}\text { Guidelines on } \\
\text { restricting rural labour } \\
\text { migration }\end{array}$ & State Council & $\begin{array}{l}\text { Strengthened the hukou system; for } \\
\text { example, RMWs are excluded from food } \\
\text { allocation in cities. }\end{array}$ \\
\hline $\begin{array}{c}\text { April, } \\
1984\end{array}$ & $\begin{array}{l}\text { Guidelines on } \\
\text { government work in } \\
\text { rural areas }\end{array}$ & СССР & $\begin{array}{l}\text { Allowed rural labour entering towns and } \\
\text { small cities }{ }^{7} \text { if they can provide food by } \\
\text { themselves. }\end{array}$ \\
\hline $\begin{array}{l}\text { October, } \\
1984\end{array}$ & $\begin{array}{l}\text { Guidelines on } \\
\text { Peasants’ settlement } \\
\text { in small towns }\end{array}$ & State Council & $\begin{array}{l}\text { 1) Supported rural labour migration to } \\
\text { towns and small cities for businesses and } \\
\text { participation in commercial and self- } \\
\text { employed jobs; } \\
\text { 2) Local authorities should provide RMWs } \\
\text { with food and housing; } \\
\text { 3) Government departments in security, } \\
\text { labour and employment should protect } \\
\text { legal economic activities of RMWs in } \\
\text { towns and small cities. }\end{array}$ \\
\hline July, 1988 & $\begin{array}{l}\text { Guidelines on } \\
\text { developing labour } \\
\text { force resources in } \\
\quad \text { poor areas }\end{array}$ & $\begin{array}{l}\text { Ministry of } \\
\text { Labour State } \\
\text { Council }\end{array}$ & $\begin{array}{l}\text { 1) Stressed the significance of rural-urban } \\
\text { migration in industrialization, } \\
\text { modernization, and economic development } \\
\text { in coastal areas in past } 20 \text { years; } \\
\text { 2) Coordinated public security authorities } \\
\text { in both receiving and sending areas to } \\
\text { improve the migration; } \\
\text { 3) Encouraged enterprises in developed and } \\
\text { coastal regions absorbing RMWs. }\end{array}$ \\
\hline
\end{tabular}

1989-1991: The employment of RMWs was restricted by the government during this period because millions of urban workers were laid-off. To resolve the unemployment of urban-hukou workers, RMWs had to be dismissed in some enterprises. In addition, the administrative regulations, such as the temporary residential permit (TRP) ${ }^{8}$, were implemented to restrict RMWs access to certain job positions.

\begin{tabular}{c|c|c|l}
\hline $\begin{array}{c}\text { December, } \\
1993\end{array}$ & $\begin{array}{c}\text { A pilot framework for } \\
\text { the labour system in } \\
\text { socialist market- } \\
\text { oriented economy }\end{array}$ & $\begin{array}{c}\text { Ministry of } \\
\text { Labour }\end{array}$ & $\begin{array}{l}\text { Abolished obstacles for rural-urban } \\
\text { migration: }\end{array}$ \\
& & $\begin{array}{l}\text { 1) The central and local governments } \\
\text { provided free employment information, }\end{array}$ \\
\hline
\end{tabular}

\footnotetext{
${ }^{7}$ Small cities are defined as those whose population is no more than 250 thousand.

${ }^{8}$ An immigrant older than 16 should obtain a temporary residential permit (TRP) in police stations within three days since arrival at the receiving places. Only those having TRPs are allowed to engage in businesses and other activities. But, the TRP has been abolished in many cities since 2008, including Shenzhen, Beijing, Taiyuan, Dalian, Guangzhou, Dongguan, Jilin, Changchun, and Zhuhai.
} 


\begin{tabular}{|c|c|c|c|}
\hline & & & $\begin{array}{l}\text { policy consultation, and training subsidies; } \\
\text { 2) Encouraged cooperation between } \\
\text { training organizations, employment } \\
\text { agencies and enterprises; } \\
\text { 3) Provided multi-level and multi-form } \\
\text { vocational trainings relevant to market } \\
\text { needs. }\end{array}$ \\
\hline June, 1997 & $\begin{array}{l}\text { An experimental } \\
\text { project on the } h u k o u \\
\text { system reform in } \\
\text { towns and cities }\end{array}$ & State Council & $\begin{array}{l}\text { 1) Allowed RMWs and their kin family } \\
\text { members to settle in towns and small cities } \\
\text { if they invested in industrial projects or } \\
\text { purchased houses in cities; } \\
\text { 2) Prohibited illegal charges imposed on } \\
\text { RMWs, such as the employment security } \\
\text { fee charged by enterprises. }\end{array}$ \\
\hline June, 2000 & $\begin{array}{l}\text { Instructions on sound } \\
\text { developing towns and } \\
\text { cities }\end{array}$ & $\begin{array}{l}\text { CCCP and State } \\
\text { Council }\end{array}$ & $\begin{array}{l}\text { RMWs in towns and small cities can apply } \\
\text { urban-hukou and those migrants with } \\
\text { urban-hukou can enjoy the same social } \\
\text { services as urban residents. }\end{array}$ \\
\hline May, 2001 & $\begin{array}{l}\text { National economic } \\
\text { and social } \\
\text { development - the } \\
10^{\text {th }} \text { five-year project }\end{array}$ & $\begin{array}{l}\text { National } \\
\text { Planning and } \\
\text { Development } \\
\text { Commission }\end{array}$ & $\begin{array}{l}\text { 1) Abolished some unfair policies for } \\
\text { RMWs in migration and employment; } \\
\text { 2) Provided RMWs with housing, } \\
\text { education, health care and other social } \\
\text { services; } \\
\text { 3) Encouraged assimilation of RMWs: } \\
\text { Propagated contributions made by } \\
\text { RMWs in urbanization; } \\
\text { Urban residents should not } \\
\text { discriminate RMWs. }\end{array}$ \\
\hline $\begin{array}{l}\text { October, } \\
2001\end{array}$ & $\begin{array}{l}\text { An experimental } \\
\text { reform on the urban } \\
\text { residence registration } \\
\text { system } \\
\end{array}$ & State Council & $\begin{array}{l}\text { Medium-sized cities }{ }^{9} \text { and some provincial } \\
\text { capitals abolished limitations on the } \\
\text { number of RMWs who can apply for } \\
\text { permanent residences. }\end{array}$ \\
\hline $\begin{array}{l}\text { November, } \\
2001\end{array}$ & $\begin{array}{l}\text { Notification of all-out } \\
\text { rectification of fees for } \\
\text { RMWs }\end{array}$ & $\begin{array}{l}\text { State Planning } \\
\text { Commission, } \\
\text { Ministry of } \\
\text { Finance } \\
\end{array}$ & $\begin{array}{l}\text { Abolished some administrative fees, } \\
\text { including the temporary residential permit } \\
\text { fee }^{10} \text {, accommodation fee, and family } \\
\text { planning fee }^{11} \text { in urban areas. }\end{array}$ \\
\hline April, 2003 & $\begin{array}{l}\text { Regulations of work- } \\
\text { related injury } \\
\text { insurances }\end{array}$ & State Council & $\begin{array}{l}\text { 1) Regulated work-related injury } \\
\text { insurances for RMWs; } \\
\text { 2) RMWs can enjoy the same subsidy } \\
\text { standard as urban residents. }\end{array}$ \\
\hline
\end{tabular}

\footnotetext{
${ }^{9}$ Medium-sized cities are defined as those whose population is between 200 and 500 thousand.

${ }^{10}$ The temporary residential permit (TRP) fee may be set differently in different areas. For instance, it is only 5 yuan/year in Beijing as compared to 36 yuan/year in Dongguan district of Guangdong.

${ }^{11}$ The family planning fee charged to rural migrants is to guarantee the "one family, one child" policy.
} 
Table A2. China's policies on the reform of ownership since 1978

\begin{tabular}{|c|c|c|c|}
\hline Date & Document & Department & Main policies \\
\hline $\begin{array}{c}\text { December, } \\
1978\end{array}$ & $\begin{array}{l}\text { The third plenum of } \\
\text { the eleventh } \\
\text { Communist Party of } \\
\text { China (CPC) }\end{array}$ & СССР & $\begin{array}{l}\text { Recovery and development of private enterprises } \\
\text { and self-employment. }\end{array}$ \\
\hline $\begin{array}{c}\text { March, } \\
1979\end{array}$ & $\begin{array}{l}\text { Approval of the } \\
\text { secretary of business } \\
\text { administration } \\
\text { meeting report }\end{array}$ & State Council & $\begin{array}{l}\text { Confirmed the legalization of self-employment. In } \\
\text { 1979, self-employment enterprises reached } 310 \\
\text { thousand. }\end{array}$ \\
\hline $\begin{array}{l}\text { September, } \\
1980\end{array}$ & $\begin{array}{l}\text { China’s first national } \\
\text { work conference on } \\
\text { labour market issues }\end{array}$ & State Council & $\begin{array}{l}\text { Increased the operational autonomy of SOEs: } \\
\text { Allowed them greater authority over the } \\
\text { allocation of profits; } \\
\text { Abolished recruitment quotas for SOEs and } \\
\text { firms are largely allowed to choose their } \\
\text { employees; } \\
\text { Allowed SOEs workers to enter into } \\
\text { collective and newly-recognized private } \\
\text { enterprises; } \\
>\text { Labour exchanges were established for the } \\
\text { registration of job vacancies, job placements, } \\
\text { and training. }\end{array}$ \\
\hline $\begin{array}{l}\text { October, } \\
1984\end{array}$ & $\begin{array}{l}\text { Decision of the CPC } \\
\text { Central Committee on } \\
\text { reform of the } \\
\text { economic system }\end{array}$ & СССР & $\begin{array}{l}\text { 1) Enterprises were required to practice } \\
\text { independent accounting and responsibility for } \\
\text { their own profits and losses. } \\
\text { 2) The traditional tie between the government and } \\
\text { work-unit-based social security was broken. }\end{array}$ \\
\hline 1985 & Pilot project in SOEs & $\begin{array}{l}\text { State Council } \\
\text { and Ministry } \\
\text { of Labour } \\
\text { (MOL) }\end{array}$ & $\begin{array}{l}\text { The specific strategies included: } \\
\text { Provided better incentives for management in } \\
\text { the form of long-term financial contracting } \\
\text { between enterprise managers and their } \\
\text { bureaucratic supervisors (Fu \& Gabriel, } \\
\text { 2001); } \\
\text { A labour contract system (laodong hetongzhi) } \\
\text { was introduced on a pilot basis to replace the } \\
\text { socialist-style lifelong employment system } \\
\text { (Seeborg et al., 2000); } \\
\text { Allowed SOEs to sell their excess output at } \\
\text { market prices, but price controls remains in } \\
\text { place for most of the output of SOEs; } \\
\text { The capital investment in SOEs changed from } \\
\text { unpaid appropriation by government to credit } \\
\text { loans by commercial banks; } \\
\text { The budget to be allocated for wages would } \\
\text { be linked to the economic performance of } \\
\text { SOEs. The indicators varied by region, local } \\
\text { consumer price index (CPI), local } \\
\text { unemployment and regional growth. The goal } \\
\text { was to provide profit-oriented incentives } \\
\text { (Yueh, 2004). }\end{array}$ \\
\hline July, 1986 & $\begin{array}{l}\text { Provisional } \\
\text { regulations on job- } \\
\text { waiting insurance for } \\
\text { employees of SOEs }\end{array}$ & State Council & $\begin{array}{l}\text { Guaranteed a basic level of living to job waiting } \\
\text { (dai ye) labours, who were either looking for their } \\
\text { first jobs or who had been laid-off. }\end{array}$ \\
\hline $\begin{array}{l}\text { September, } \\
1986\end{array}$ & $\begin{array}{l}\text { Three working } \\
\text { regulations of SOEs }\end{array}$ & $\begin{array}{c}\text { CCCP and } \\
\text { State Council }\end{array}$ & $\begin{array}{l}\text { The three working regulations of SOEs were: } \\
\text { working regulations of enterprise managers in } \\
\text { SOEs; working regulations of grass-roots }\end{array}$ \\
\hline
\end{tabular}




\begin{tabular}{|c|c|c|c|}
\hline & & & $\begin{array}{l}\text { organization; and working regulations of workers } \\
\text { congress. } \\
\text { The core point of the regulations: } \\
\text { Enterprise manager was responsible for all } \\
\text { affairs in SOEs, such as decision-making } \\
\text { power; } \\
\text { It was important to strengthen the } \\
\text { collaboration of administration, party } \\
\text { organization, and workers congress to } \\
\text { improve productivity. }\end{array}$ \\
\hline $\begin{array}{l}\text { December, } \\
1986\end{array}$ & $\begin{array}{l}\text { Regulations of } \\
\text { deepening the reform } \\
\text { of SOEs and } \\
\text { strengthening } \\
\text { enterprise vitality }\end{array}$ & State Council & $\begin{array}{l}\text { SOEs can implement diverse forms of operation } \\
\text { mechanisms, such as lease and contracting. }\end{array}$ \\
\hline $\begin{array}{l}\text { October, } \\
1987\end{array}$ & $\begin{array}{l}\text { The thirteenth } \\
\text { National Congress of } \\
\text { CPC }\end{array}$ & CCCP & $\begin{array}{l}\text { 1) Confirmed the legalization of private } \\
\text { enterprises; } \\
\text { 2) Indicated that private enterprises are one } \\
\text { supplementary type for SOEs. In 1989, private } \\
\text { enterprises reached } 200 \text { thousand and their } \\
\text { employees rose to } 1.85 \text { million. }\end{array}$ \\
\hline 1990 & $\begin{array}{l}\text { Regulations of further } \\
\text { promoting the } \\
\text { development of self- } \\
\text { employed and private } \\
\text { enterprises }\end{array}$ & State Council & $\begin{array}{l}\text { Encourage the development of private enterprises: } \\
>\quad \text { Decreased financial tax for private } \\
\text { enterprises; } \\
>\quad \text { Private enterprises can get the tax } \\
\text { reimbursement from local authorities. }\end{array}$ \\
\hline June, 1991 & $\begin{array}{l}\text { Decision on the } \\
\text { reform of the pension } \\
\text { insurance system for } \\
\text { urban enterprise } \\
\text { employees }\end{array}$ & State Council & $\begin{array}{l}\text { Introduced universal social pooling of pension } \\
\text { insurance to alleviate the imbalance of pension } \\
\text { burdens among different enterprises. }\end{array}$ \\
\hline $\begin{array}{c}\text { August, } \\
1992\end{array}$ & $\begin{array}{c}\text { Suggestions of } \\
\text { improvement of wage } \\
\text { distribution of SOEs }\end{array}$ & $\begin{array}{l}\text { State Council } \\
\text { and MOL }\end{array}$ & $\begin{array}{l}\text { Enterprises were permitted to set their internal } \\
\text { wage structure within the confine of the overall } \\
\text { wage budget established by the government. If the } \\
\text { wage bill exceeded the governmental standard } \\
\text { wage bill, a wage adjustment tax of 33\% must be } \\
\text { paid to the Department of Taxation. }\end{array}$ \\
\hline $\begin{array}{l}\text { October, } \\
1992\end{array}$ & $\begin{array}{l}\text { The fourteenth } \\
\text { National Congress of } \\
\text { CPC }\end{array}$ & СССР & $\begin{array}{l}\text { 1) Confirmed that the China's economic system } \\
\text { consists of the dominant state ownership while } \\
\text { diverse forms of non-state ownership were } \\
\text { allowed to co-exist, including private, self- } \\
\text { employed and foreign-owned; } \\
\text { 2) Further encouraged the development of private } \\
\text { and self-employed enterprises: } \\
\text { Widened the scope of operation in private } \\
\text { enterprises from a unilateral form to diverse } \\
\text { forms, including processing, retail, wholesale, } \\
\text { freight services, repair services, loading, and } \\
\text { consulting services; } \\
\text { Allowed private and self-employed } \\
\text { enterprises to engage in some industries } \\
\text { related to national safety and people's health, } \\
\text { including production and supply of } \\
\text { electricity, gas and water, as well as finance } \\
\text { and insurance. }\end{array}$ \\
\hline May, 1993 & $\begin{array}{l}\text { Regulations on job- } \\
\text { waiting insurance for } \\
\text { employees of SOEs }\end{array}$ & State Council & $\begin{array}{l}\text { 1) Amended the provisional regulations of 1986; } \\
\text { 2) Broadened the scope of coverage to all SOEs }\end{array}$ \\
\hline
\end{tabular}




\begin{tabular}{|c|c|c|c|}
\hline & & & 3) Enhanced the level of benefits. \\
\hline $\begin{array}{l}\text { November, } \\
1993\end{array}$ & $\begin{array}{l}\text { The third plenum of } \\
\text { the fourteenth CPC } \\
\text { congress }\end{array}$ & СССР & $\begin{array}{l}\text { 1) Improved the number and market share of } \\
\text { private and self-employed enterprises; } \\
\text { 2) SOEs should dominate the market share in } \\
\text { critical industries related to national safety and } \\
\text { people's health; } \\
\text { 3) Endorsed the development of diversified forms } \\
\text { of enterprise ownership. Large and medium state } \\
\text { enterprises were subsequently converted into } \\
\text { limited liability shareholding companies, in order } \\
\text { to separate government and business functions } \\
\text { and to create transferable ownership shares. }\end{array}$ \\
\hline 1994 & $\begin{array}{c}\text { Suggestions of } \\
\text { improvement of wage } \\
\text { distribution of SOEs }\end{array}$ & $\begin{array}{l}\text { State Council } \\
\text { and MOL }\end{array}$ & $\begin{array}{l}\text { Enterprises that are publicly listed companies } \\
\text { were permitted to set their own wages, but subject } \\
\text { to two standards. The first was that the growth } \\
\text { rate of total wages must be lower than that of } \\
\text { after-tax profitability and the second was that per } \\
\text { capita wage growth was lower than the rate of } \\
\text { growth of labour productivity (Yueh, 2004). }\end{array}$ \\
\hline $\begin{array}{c}\text { December, } \\
1994\end{array}$ & $\begin{array}{c}\text { Pilot project in } \\
\text { medical insurance } \\
\text { system of SOEs }\end{array}$ & State Council & $\begin{array}{l}\text { Zhenjiang and Jiujiang cities were chosen to for } \\
\text { the pilot project in which social pooling of } \\
\text { medical insurance premiums would be combined } \\
\text { with individual accounts. }\end{array}$ \\
\hline $\begin{array}{l}\text { March, } \\
1995\end{array}$ & $\begin{array}{l}\text { Circular on deepening } \\
\text { reform of pension } \\
\text { insurance system for } \\
\text { enterprises employees }\end{array}$ & State Council & $\begin{array}{l}\text { A transition from the expenses of social security } \\
\text { effectively paid by the government to partial } \\
\text { accumulation of funds and individual } \\
\text { contributions for pension. }\end{array}$ \\
\hline $\begin{array}{l}\text { September, } \\
1995\end{array}$ & $\begin{array}{l}\text { The fifth plenum of } \\
\text { the fourteenth CPC } \\
\text { congress }\end{array}$ & ССCP & $\begin{array}{l}\text { 1) Encouraged the development of private and } \\
\text { self-employed enterprises: } \\
\text { They can enjoy the same treatments as SOEs } \\
\text { in applying projects, import and export, } \\
\text { investments, and land use; } \\
\text { The financial tax was charged based on the } \\
\text { standards set by the central government. } \\
\text { Local authorities were not allowed to add } \\
\text { additional fees on private and self-employed } \\
\text { enterprises; } \\
\text { 2) The Ninth Five Year Plan (1996-2000) was } \\
\text { implemented to overhaul the previous six } \\
\text { components of the wage of SOEs into two } \\
\text { components: fixed (guding) and variable (huo). } \\
\text { The fixed portion included the basic wage, } \\
\text { seniority wage, and benefits of housing, pension, } \\
\text { medical and unemployment, while the variable } \\
\text { portion referred to bonus depending on an } \\
\text { individual's productivity and an enterprise's } \\
\text { profitability. }\end{array}$ \\
\hline 1996 & $\begin{array}{l}\text { Resolution on } \\
\text { establishing the basic } \\
\text { medical insurance } \\
\text { system for employees } \\
\text { in urban areas }\end{array}$ & State Council & $\begin{array}{l}\text { 1) Expand the coverage of medical insurance } \\
\text { reform based on the pilot project implemented in } \\
\text { 1994; } \\
\text { 2) Individuals were required to pay a proportion } \\
\text { of their medical expenses; } \\
\text { 3) Adopted the cooperative medical system. }\end{array}$ \\
\hline $\bar{M}$ & $\begin{array}{l}\text { Notification of reform } \\
\text { and development of } \\
\text { SOEs }\end{array}$ & $\begin{array}{l}\text { State Council } \\
\text { and State } \\
\text { Economic and } \\
\text { Trade }\end{array}$ & $\begin{array}{l}\text { The policy such as downsizing and promoting the } \\
\text { layoff of workers by a quarter or more within four } \\
\text { years was implemented to resolve the problem of } \\
\text { inefficiency of SOEs. }\end{array}$ \\
\hline
\end{tabular}




\begin{tabular}{|c|c|c|c|}
\hline & & Commission & \\
\hline $\begin{array}{c}\text { September, } \\
1997 \\
\end{array}$ & $\begin{array}{l}\text { The fifteenth National } \\
\text { Congress of CPC }\end{array}$ & СССР & $\begin{array}{l}\text { Non-SOEs were one important component in the } \\
\text { socialist market economy. }\end{array}$ \\
\hline June, 1998 & $\begin{array}{l}\text { Circular on } \\
\text { guaranteeing the basic } \\
\text { life of laid-off workers } \\
\text { of SOEs and making } \\
\text { arrangements for their } \\
\text { reemployment }\end{array}$ & $\begin{array}{l}\text { State Council } \\
\text { and CCCP }\end{array}$ & $\begin{array}{l}\text { 1) Required all SOEs that have laid-off workers } \\
\text { should establish a reemployment service centre to } \\
\text { guarantee the basic living of laid-off workers and } \\
\text { endeavour to promote their reemployment; } \\
\text { 2) If workers lost their jobs, the enterprises will } \\
\text { not be responsible for them and they will directly } \\
\text { enter the unemployment insurance network. }\end{array}$ \\
\hline $\begin{array}{c}\text { August, } \\
1998\end{array}$ & $\begin{array}{l}\text { Circular on } \\
\text { implementing the } \\
\text { pooling of basic } \\
\text { pension for enterprise } \\
\text { employees at the } \\
\text { provincial level and } \\
\text { local administration }\end{array}$ & State Council & $\begin{array}{l}\text { Accelerated the transition of the level of pooling } \\
\text { basic pensions to the provincial level and to } \\
\text { transfer the trade-based pooling of basic pension } \\
\text { insurance in } 11 \text { major industries, such as } \\
\text { electricity/gas/water production and supply. }\end{array}$ \\
\hline 1998 & $\begin{array}{l}\text { Regulations on the } \\
\text { administrative system } \\
\text { of social security }\end{array}$ & State Council & $\begin{array}{l}\text { 1) The Ministry of Labour and Social Security } \\
\text { was established in 1998, which was designed to } \\
\text { administer social insurance for individuals } \\
\text { associated with enterprises, state institutions, } \\
\text { public service units and rural areas on a unified } \\
\text { basis; } \\
\text { 2) The Ministry of Civil Affairs is responsible for } \\
\text { administrating the affairs of social relief and } \\
\text { social welfare; } \\
\text { 3) Progress has also been made in the reform of } \\
\text { the work injury insurance system, maternity } \\
\text { insurance system and other social security. }\end{array}$ \\
\hline $\begin{array}{l}\text { January, } \\
1999\end{array}$ & $\begin{array}{l}\text { Regulations on } \\
\text { unemployment } \\
\text { insurance }\end{array}$ & State Council & $\begin{array}{l}\text { 1) The name of job-waiting was formally replaced } \\
\text { by the name of unemployment and the coverage } \\
\text { was extended to include all enterprises and public } \\
\text { service units in urban areas; } \\
\text { 2) Individual workers must contribute } 1 \% \text { of their } \\
\text { payment wage as unemployment premiums. }\end{array}$ \\
\hline $\begin{array}{l}\text { November, } \\
2002\end{array}$ & $\begin{array}{l}\text { The sixteenth National } \\
\text { Congress of CPC }\end{array}$ & ССCP & $\begin{array}{l}\text { 1) Restated non-SOEs were one important } \\
\text { component in the socialist market economy; } \\
\text { 2) SOEs and non-SOEs can coexist in the labour } \\
\text { market; } \\
\text { 3) Confirmed that the economic system was } \\
\text { composed of public ownership and various types } \\
\text { of non-SOEs. }\end{array}$ \\
\hline $\begin{array}{l}\text { October, } \\
2003\end{array}$ & $\begin{array}{l}\text { The thirteenth plenum } \\
\text { of the sixteenth CPC }\end{array}$ & СCCP & $\begin{array}{l}\text { 1) Proposed firstly to promote the development of } \\
\text { joint-venture enterprises; } \\
\text { 2) Further reduced restrictions to non-SOEs and } \\
\text { allow them to engage in some monopolized } \\
\text { industries, such as education, culture, arts, } \\
\text { broadcast, movies, television and public utilities. }\end{array}$ \\
\hline $\begin{array}{l}\text { March, } \\
2004\end{array}$ & $\begin{array}{l}\text { The second session of } \\
\text { the tenth National } \\
\text { People's Congress }\end{array}$ & CCCP & Stated firstly that private property was inviolable. \\
\hline
\end{tabular}

Notes: The specific policy measures relating to social security and welfare benefits are referenced by Dong and Ye (2003) and $\mathrm{Gu}(2001)$. 
Table A3. Urban employment by different ownership enterprises during 1980-2002

\begin{tabular}{lccccc}
\hline & 1978 & 1990 & 1995 & 2000 & 2002 \\
\hline \multirow{3}{*}{ Urban employment } & \multicolumn{5}{c}{ Million (percent of total) } \\
\cline { 2 - 6 } SOEs & 103.3 & 170.5 & 190.4 & 231.4 & 237.1 \\
& $(100.0)$ & $(100.0)$ & $(100.0)$ & $(100.0)$ & $(100.0)$ \\
UCEs & 79.2 & 103.5 & 112.6 & 81.0 & 75.1 \\
& $(76.7)$ & $(60.7)$ & $(59.1)$ & $(35.0)$ & $(31.7)$ \\
Private & 23.6 & 35.5 & 31.5 & 15.0 & 12.5 \\
Foreign-owned & $(22.8)$ & $(20.8)$ & $(16.5)$ & $(6.5)$ & $(5.3)$ \\
& 0.5 & 6.7 & 20.6 & 34.0 & 36.6 \\
Joint venture & $(0.5)$ & $(3.9)$ & $(10.8)$ & $(14.7)$ & $(15.4)$ \\
& 0.0 & 0.7 & 5.1 & 6.4 & 6.7 \\
Other & $(0.0)$ & $(0.4)$ & $(2.7)$ & $(2.8)$ & $(2.8)$ \\
& 0.0 & 1.0 & 3.7 & 13.4 & 15.2 \\
& $(0.0)$ & $(0.6)$ & $(1.9)$ & $(5.8)$ & $(6.4)$ \\
& 0.0 & 23.1 & 16.9 & 81.6 & 91.6 \\
\end{tabular}

Note: SOEs include the employment in the institutions; UCEs denote urban collective-owned enterprises. Other includes selfemployed and other share-holding enterprises. Source: China Statistical Yearbook, various years, NBSC.

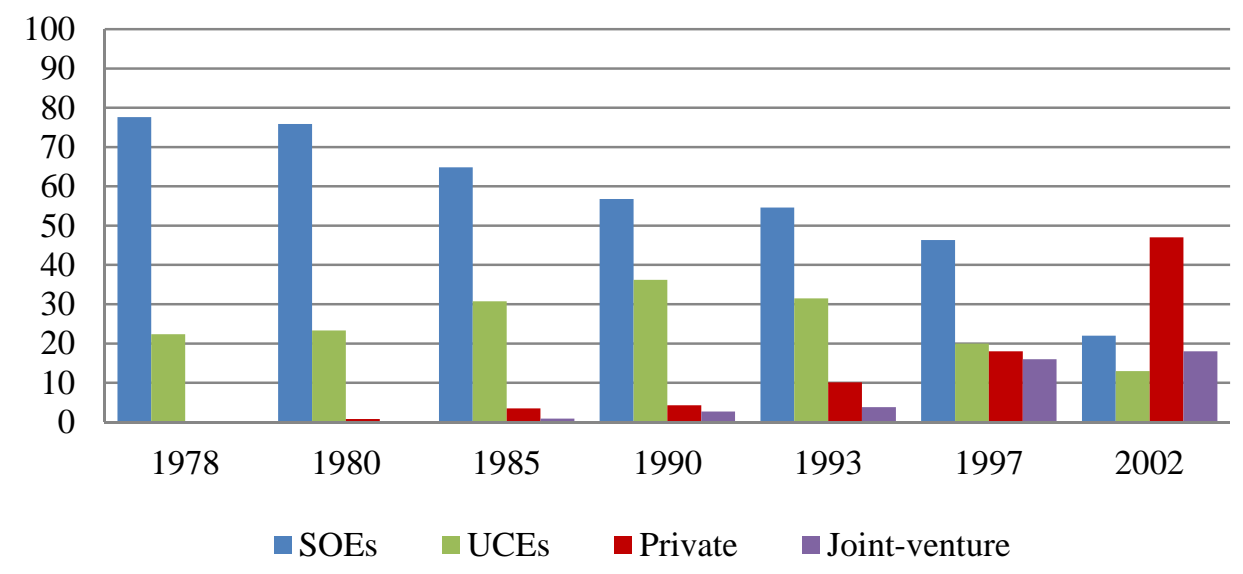

Fig. A1. Gross industrial output value by ownership - percent of the total value during 1978-2002.

Source: China Industrial Statistical Yearbook, various years, NBSC (Brooks \& Tao, 2003; Qian \& Xu, 1993). 
TableA4. Category of industry

\begin{tabular}{|c|c|c|}
\hline Industries & Employmen & ge (\%) \\
\hline & 1995 & 2002 \\
\hline \multicolumn{3}{|l|}{ Industries with low employment percentage } \\
\hline \multirow{2}{*}{ Geological prospecting, irrigation administration } & \multirow{2}{*}{0.07} & 0.23 \\
\hline & & 0.03 \\
\hline Electricity, gas and water production and supply & - & 0.68 \\
\hline Finance and insurance & 0.27 & 0.29 \\
\hline Real estate & 0.07 & 0.70 \\
\hline Scientific research and professional services & 0.14 & 0.38 \\
\hline Health, sports and social welfare & 0.34 & 1.14 \\
\hline Education, culture, arts, broadcast, movies, television & 0.27 & 1.35 \\
\hline Government agents, party organizations and social groups & 0.21 & 1.17 \\
\hline & 0.75 & - \\
\hline $\begin{array}{r}\text { Materials supply and marketıng, warehousing } \\
\text { public utilities }\end{array}$ & 0.14 & - \\
\hline Transportation, storage, post office and communication & 2.88 & 2.67 \\
\hline \multicolumn{3}{|l|}{ Other industries } \\
\hline Manufacturing & - & 9.80 \\
\hline Industry & 29.34 & - \\
\hline Construction & 24.40 & 4.73 \\
\hline Wholesale, retail and food services & 9.93 & 47.02 \\
\hline Social service & 3.56 & 21.34 \\
\hline other & 27.62 & 8.45 \\
\hline Number of Obs. & 1,459 & 3,407 \\
\hline
\end{tabular}

Note: Other indicates the other industries and farm, forestry, husbandry, and fishery.

Source: CHIP 1995, 2002, rural migrant samples. 